\title{
Archipel
}

ARCHIPEL Études interdisciplinaires sur le monde insulindien

$96 \mid 2018$

Varia

\section{New Evidence on the Origin of the Hikayat Muhammad Hanafiyyah}

Nouvelles preuves sur l'origine de l'Hikayat Muhammad Hanafiyyah

\section{Majid Daneshgar}

\section{(2) OpenEdition}

1 Journals

\section{Electronic version}

URL: http://journals.openedition.org/archipel/793

DOI: 10.4000/archipel.793

ISSN: 2104-3655

\section{Publisher}

Association Archipel

\section{Printed version}

Date of publication: 15 November 2018

Number of pages: 69-102

ISBN: 978-2-910513-80-1

ISSN: 0044-8613

\section{Electronic reference}

Majid Daneshgar, "New Evidence on the Origin of the Hikayat Muhammad Hanafiyyah », Archipel [Online], 96 | 2018, Online since 20 November 2018, connection on 23 November 2020. URL : http:// journals.openedition.org/archipel/793; DOI : https://doi.org/10.4000/archipel.793 
VARIA

MAJID DANESHGAR ${ }^{l}$

\section{New Evidence on the Origin of the Hikayat Muhammad Hanafiyyah}

\section{Introduction: Early Hypotheses ${ }^{2}$}

It is a commonly-held view amongst scholars that the Hikayat Muhammad Hanafiyyah $^{3}$ (henceforth $H M H$ ) is one of the oldest Islamic popular romances of Malay Islamic literature and culture. According to the 23rd chapter of the Sejarah Melayu, for example, this story was recited by Malaccans at the time of the Portuguese siege of Malacca in $1511^{4}$. This in turn suggests that Malays were familiar with $H M H$ 's features and qualities (khawāsss) by that time, and they could use it during wars, conflicts, and disasters. Scholars have been investigating the contribution of $H M H$ to the Islamization of the Malay World since the turn of

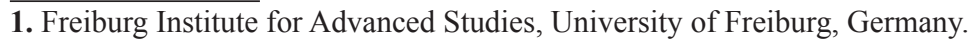

2. This work is part of a larger research project at the Freiburg Institute for Advanced Studies (FRIAS), University of Freiburg, Germany, where I work as a Junior Fellow and Marie S. Curie Fellow of the European Union. This article would not have been possible without the kind support of the FRIAS and Johanna Pink (from the Orientalisches Seminar, University of Freiburg). I also thank Edwin Wieringa (University of Cologne) for reading the draft of this article and providing me with his helpful comments. My thanks go to Michael Lecker (Hebrew University of Jerusalem) and Andreas Goerke (University of Edinburg) for sharing valuable information about Muhammad b. al-Hanafiyyah with me. I also thank the University of Leiden Library (the Netherlands), the Ganj baksh Collection Library (Pakistan) and the Sir George Grey Special Collections, Auckland Libraries (New Zealand) for granting permission to access their collections and use images of their manuscripts.

3. In written form, "Hanafiyyah" is sometimes rendered "Ḥanafiyya" or "Hanīfah."

4. Sejarah Melayu or Malay Annals. An annotated translation by C.C. Brown, with a new introduction by R. Roolvink, Kuala Lumpur, Oxford University Press, 1970, pp. 162-163. 
the 20th century; they have believed that the more we understand of $H M H$ 's origin, the more we we will be able to understand about Islam in this region. According to Edwin Wieringa, this story "was not only received into Malay literature at an early period, but it has remained popular a long time, [since the 19th century] one of the best-sellers of the indigenous press." 5

Van Ronkel was one of the first scholars to attempt to uncover the origin of $H M H$. In the late 19th century, he connected this story to sources in Persian; going through the $H M H$ manuscripts held in the Cambridge University Library, he noted the existence of various Persian terms throughout the text. Later, he expanded his theory by referring to Charles Rieu's catalogue of the Persian manuscripts in the British Museum (now in the British Library), in which manuscript Add. 8149 is listed. ${ }^{6}$ This Persian manuscript was copied in the Murshidabad region of Bengal in 1134-5/1721 and is composed of two parts. Van Ronkel concluded that the Malay $H M H$ is a rendering of these two Persian parts: (i) Qisșa-yi amīr al-mu 'mininn Hassan va Husayn (fols. 1-28); and (ii) Hikāyat-i Muhammad Hanafiyyah (fols. 29-82) ${ }^{7}$. Winstedt agreed, stating that "though in Arabic there are biographies of Muhammad Hanafiyyah, only in Persian is there a special hikayat."

However, scholars have been unsure as to whether both the Persian and the Malay versions were "one unified text, consisting of two or more parts, or [...] two or more originally independent fragments which have been combined." Winstedt, Voorhoeve, and Brake ${ }^{10}$ have all pointed out that some Malay versions of $H M H$ are prefaced with another mystical story about the creation of Muhammad and his light, known as Hikayat Nur Muhammad (henceforth $H N M$ ), which is not found in the Persian version..$^{11}$ As such, Brakel suggested that the Malay romance includes three sections: (a) Hikayat Nur Muhammad; (b) Hikayat Hasan dan Husain, "mainly about these two sons of 'Alī, up to their death"; and (c) $H M H$, "describing the war of "Alī's third son Muhammad

5. Edwin Wieringa, "Does Traditional Islamic Malay Literature Contain Shi'itic Elements? 'Alī and Fātimah in Malay Hikayat Literature," Studia Islamika 3/4, 1996, pp. 93-111.

6. Ph. S. van Ronkel, "Account of six Malay manuscripts of the Cambridge University Library," Bijdragen tot de Taal-, Land- en Volkenkunde 46/1, 1896, pp. 1-53; see also Winstedt, A History of Classical Malay Literature, Singapore, Malayan Branch of the Royal Asiatic Society, 1939, p. 106.

7. Charles Rieu, Catalogue of the Persian Manuscripts in the British Museum, London, The British Museum, 1881, vol. 2, p. 819; V. Braginsky, The Heritage of Traditional Malay Literature: A Historical Survey of Genres, Writings and Literary Views, Leiden, KITLV Press, 2005, pp. 181-182.

8. Winstedt, 1939, p. 107.

9. L.F. Brakel (a), The Hikayat Muhammad Hanafiyyah: A Medieval Muslim-Malay Romance, Berlin, Springer, 1981, p. 16.

10. Hence, Brakel is the one who provided readers with the most comprehensive edition of the Malay $H M H$; this article inevitably refers to his works frequently.

11. Winstedt, 1939, p. 107; Brakel (a), p. 16. See also P. Voorhoeve, "Les manuscrits malais de la Bibliothèque Nationale de Paris," Archipel 6, 1973, pp. 42-80. 
ibn al-Hanafiyyah with Yazīd," the son of Mu'âwiya, the founder of the Umayyad dynasty. ${ }^{12}$

Additionally, Brakel found that one of the oldest manuscripts of the Malay $H M H$, from the 17th century, includes a colophon that says "tammat hikayat maqatil Husain dan MH" ("the story of Husayn's death as well as Muhammad Hanafiyyah is finished"). ${ }^{13}$ Following Bausani, Brakel declared that the term maqtal, ${ }^{14}$ which is very common in Middle Eastern literary works and refers to the killing of Husayn at Karbala in $680 \mathrm{CE}$, has been known in the Archipelago since the 16th century. Brakel also highlighted the commonalities between the Persian and Malay HMHs. In short, he, along with most other scholars, believes that the Malay version of $H M H$ was not only influenced by Persian literary works but seems to be a direct translation of a Persian work probably written in the 14th century. The two most important conclusions about the date of the British Library Persian manuscript Add. 8149, as presented by Brakel, are that:

- The Persian manuscript includes terms, names, and phrases found in Firdawsi's (d. c. $1020 \mathrm{CE}$ ) Shäh-nāma or the Satire on Mahmūd of Ghazne. Therefore, it must have been influenced by Firdawsi's writing.

- The city of Tughan Turk, Tabriz, whose name is mentioned in both the Persian and Malay stories of Muhammad Hanafiyyah, was the capital of Ghazan Khan from 1295 until $1304 \mathrm{CE}^{15}$.

Therefore, $H M H$ must have been written after these dates. In order to prove his findings, Brakel produced an edition and translation of the Malay HMH entitled The Story of Muhammad Hanafiyyah in 1977. He believed that chapters 2-4 and 21-26 of Part I and chapters 1-17 and 20-21 of Part II "could be traced in the Persian" manuscript Add. 8149. ${ }^{16}$

However, Brakel and other scholars remained uncertain about: (a) various aspects of the Persian original, such as its author, date, and main features ${ }^{17}$; and (b) whether or not Hikayat Hasan dan Husayn or maqtal (part I) was originally associated with $H M H$ (part II), or with $H N M$. This article seeks to build on previous studies of $H M H$ by shedding some light on details of

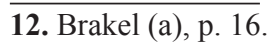

13. Ibid., p. 24.

14. Maqātil is the plural form of maqtal.

15. Brakel (a), p. 54.

16. L.F. Brakel (b), The Story of Muhammad Hanafiyyah, Leiden, Koninklijk Instituut Voor Taal-, Land- en Volkenkunde, 1977, p. v.

17. Brakel (a), p. 54. 
the Persian original. The following sections will discuss the background of the Persian text the author has seen and its relationship with the Malay $H M H$. In order to achieve the latter, the following subjects will be examined:

- The similarities between various types of the Persian original (prototype) and the chapters in Brakel's edition of the Malay $H M H$, which are traced in Add. 8149;

- The common points between our Persian prototype and Brakel's edition of the Malay $H M H$ that are not found in Add. 8149.

- A discussion of the arguments of former scholars of $H M H$ in the light of the Persian prototype.

\section{The Persian Prototype}

While compiling a catalogue of Islamic writings kept in various libraries in New Zealand, ${ }^{18}$ I came across several manuscripts of one text. It is called Durr al-Majālis, also written as Durr-i Majālis ("The Jewel of Remembrance Sessions," henceforth $D M J$ ) and was written by Sayf al-Dīn Zafar Nawbahārī Bukhārī, ${ }^{19}$ a religious and mystical figure from the late 7 th century $\mathrm{AH} / 13$ th century $\mathrm{CE}^{20}$. As part of the present study I consulted all full or partial manuscripts of $D M J$ that are preserved in libraries around the world (see the appendix). The work has 33 chapters, although the titles, order, and length of these vary from manuscript to manuscript. Upon reading them, it became apparent that a number of chapters have titles or parts of stories that are similar to those of the Malay hikayat, such as: "Dar Hikāyat-i [Sulțān] Ibrāhīm Adham" ("The Story of [Sultan] Ibrāhīm Adham"); "Dar Hikāyat-i Amīr al-Mu'minīn 'Alī rad̄̄ Allāh 'anhu bā Khātūn-i Qiyāmat Fātimah Zahrā"' ("On the Story of the Commanders of the Believers, 'Alī, and the Lady of the Judgment Day, Fāțimah") 21; Dar Faḍ̄lat-i Yūsuf ("On the Virtues of Joseph");

18. See Majid Daneshgar, Middle Eastern and Islamic Manuscripts Held at Sir George Grey Special Collections Auckland Libraries New Zealand, Auckland, N.Z., Sir George Grey Special Collections, Auckland Libraries, 2018; Majid Daneshgar and Donald Kerr, Middle Eastern and Islamic Materials in Special Collections University of Otago, Dunedin, N.Z., Special Collections, University of Otago Library, 2017.

19. His name is rendered slightly differently in some copies, as Sayf al-Dīn Zafar Bothohārī, Nūr-Bahārī, Tothohārī or Pothohārī, Sayf al-Dīn Zafar b. Burhān, Sayf Zafar 'Alī, and, on one occasion, very differently, as Yūsuf Zafar Abū Țāhir.

20. Sayyid Mahmūd Mar'ash̄̄ Najafî, Fihrist-i Nuskha-hā-yi Khatti-yi Kitāb-khāna-yi Buzurg-i Āyatuliāh Mar'ashī Najafī, Qum, Kitāb-khāna-yi Buzurg-i Āyatullāh Mar'ash̄̄ Najafî, 1383/2004, vol. 32, no. 12750, and no. 10680, p. 405; Muhammad Hossein Nūrī-niā et al. Fihrist-i Nuskha-hā-yi Khațtīi, Mashhad, Sāzmān-i Kitāb-khāni-hā, Mūzi-hā va Markaz-i Asnād-i Āstān-i Quds-i Razavī, 1388/2009, Manuscript no. 40539, p. 75.

21. An alternative title is: "Dar Hikāyat Amīr al-Mu'minīn 'Alī Karram Allāh Wajhah bā Khātūn-i Jannat Fätimah Zahra" ("On the Story of the Commanders of the Believers, 'Alī, and the Lady of the Paradise, Fātimah"). 
"Dar Hikāyat-i Mard-i Sakhì va Zan-i Bakhīl" ("On the Story of the Generous Man and Miserly Woman"); "Dar Fadīlat-i Peyghāmbar-i Mā, Hadrat-i Muhammad" ("On the Virtue of Our Messenger, the Prophet Muhammad"); "Haqq-i Yatīmān ("The Orphans' Rights"); "Dar Hikāyat-i Māriyah Qibțiyah" ("The Story of Māriyah Qibțiyah"); "Dar Fadīlat-i Khālid b. Walìd" ("On the Virtues of Khālid b. Walīd"); "Dar Hikāyat-i Shaykh Barsīsä" (?) ("On the Story of Shaykh Barșiṣāa"), and so on. A full assessment of the connection between the aforementioned stories with those found in various Malay texts will be the subject of a future study. Interestingly, the Pashto works of Tawallud-näma ("The Story of the Birth and Lives of Hassan and Husayn") and Jang-nāma-i Imāmayn ("The Battle and Killing Story of the Two Imāms in Karbala") by, for example, Ghulām Muhammad Gagyān̄̄/Gigyānī in the late 18th and early 19th century, were written "on the basis of the account in the Persian [work of] Durr-i Majālis by Sayf ul-Zafar Naw-bahārī."22

The oldest manuscripts of $D M J$ I consulted are Or. 565, preserved in Leiden University Library in the Netherlands (henceforth OL), and dated Safar 972/1564, and PAK-001-0770 (henceforth OP), kept in the Ganj bakhsh Collection, Islamabad, Pakistan, and dated 1092/1681 (fig. 1). This study will focus on one of the last chapters of DMJ, entitled "Dar Maqtal-i Amìr al-Mu'minin [Imām] Hassan va [Imām] Husayn" ("On the Killing of the Commanders of the Believers Hassan and Husayn"). The 31st chapter of OL (folios: 214-226) and OP (folios: 267-302), entitled "dar maqtal-i/qatl-i Imām/ Amīr al-Mu minīn Hassan va Husayn Raḍī Allāh," are identical to each other, ${ }^{23}$ and their content and length largely resemble that of most $D M J$ manuscripts. However, they are considerably shorter and incomplete compared to two other copies of $D M J$ that were apparently copied in the late 18th or early 19th centuries: (a) GMS 170, The National Library of Auckland, New Zealand (henceforth GA); and (b) PAK-001-1498, Ganj bakhsh Collection, Pakistan (henceforth NP).

It was the existence of the similarities between this one chapter of $D M J$ and the Malay manuscripts of $H M H$ that led me to write this article.

22. See James Fuller Blumhardt and D.N. MacKenzie, Catalogue of Pashto Manuscripts in the Libraries of the British Isles, London, The Trustees of the British Museum and the Commonwealth Relations Office, 1965, pp. 108-114.

23. Nonetheless, the table of contents shows it as "dar maqātil-i Amīr al-Mu' minīn Hasan va Amīr al-Mu minīn Husayn Raḍī-allāh 'anh.” 

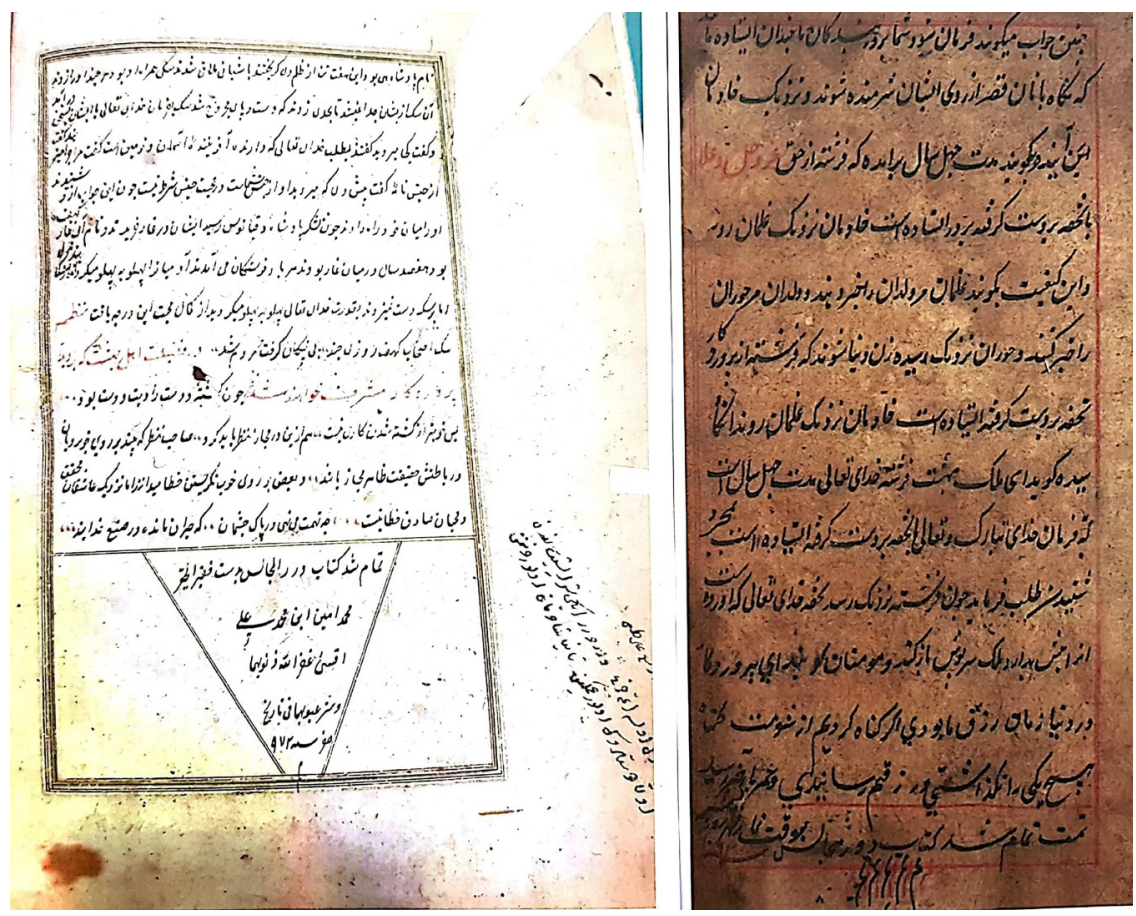

Fig. 1 - From left to right: the colophons of OL and OP

For instance, different copies of $D M J$ start part I with titles such as:

/ بر مقاتل امير المونين حسن و امير المونين حسين رضى الله عنه (OL/OP) -

"On the Killings of the Commander of the Believers Hasan and the Commander of the Believers Husayn, May God Be Pleased with Him [Them]"

/ در مقتل امير المونين (امام) حسن و (امام) حسين رضى الله عنه (GA and NP) -

"On the Killing of (Imām) Ḥasan and (Imām) Ḥusayn, May God Be Pleased with Him"

| (1959 Vienna) - در مقتل امير المونين حسين

"On the Killing of the Commander of the Believers, Husayn"

/ در حكايت معاويه (PAK-001-1506)

"On the Story of Mu' āwiya" 
Malay $H M H$ MSS D5, preserved in the British Library, includes the following titles for the first part:

- (D 5) (اين حكايه محمد حنفيه (

"This is the Story of Muhammad Hanafiyya"

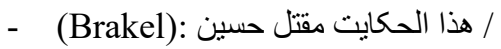

"This is the Story of the Killing of Husayn"

On another occasion, the interest of Hasan and Husayn in the fruits brought to them by Dihyah al-Kalbī is seen in both the Persian and Malay texts ${ }^{24}$ :

$(\mathrm{OL} / \mathrm{OP})$

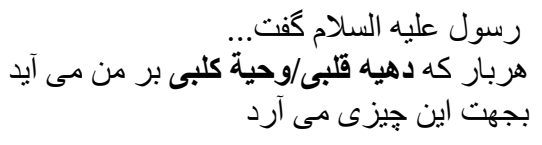

(D 5)

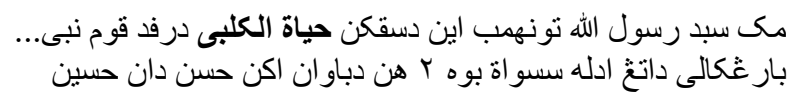

This is despite the fact that Dihyah al-Kalbī's name is misspelt in the Persian texts (OL/OP) and in the Malay version (D 5). Gabriel then brings them heavenly fruit - only a pomegranate $(a n \bar{a} r)$ in the Persian version, both a pomegranate (delima) and a grape (anggur) in the Malay.

There are also references to Hasan's and Husayn's demand for the feast garment. Hasan received a green one, symbolizing his death with poison, and Husayn had the blood-red one, reflecting his murder in Karbala ${ }^{25}$ :

$(\mathrm{OL} / \mathrm{OP})$

(D 5)

$$
\begin{aligned}
& \text { جامه سبز بيرون آمد آنر ا به حسن داد... } \\
& \text { و جامه لعل كثنته بـه حسين داد آنداد }
\end{aligned}
$$

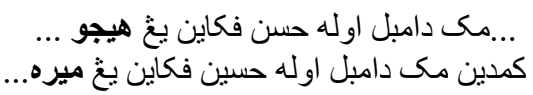

The Story of Husayn's Death in DMJ: General Overview

In manuscripts OL and OP, the chapter begins with the death of Mu'āwiya

24. English translations are found in the table, below.

25. English translations are found in the table, below. 
and Yazīd's attempts to destroy Hassan and Husayn and ends with the captivity of Husayn's family and their presence in Yazīd's palace. Not only do GA (fols: 129-47) and NP (fols: 449-88) contain OL's/OP's stories, but they also add a number of events and elements to them (part I). Regarding the first part of this chapter in the $D M J$ manuscripts, a number of points should be highlighted:

- In most manuscripts, excluding GA and NP, this chapter concludes with a scene in the palace.

- In most manuscripts, except GA, this scene ends with the unsuccessful attempt by a specific servant (whose name, according to some $D M J$ copies and Add. 8149, was Șāliḥ) to kill Yazīd and his subsequent wanderings, unhappy and overburdened by the disasters of life. OP, for example, says: "[...] chun ghulām ìn sukhan bishnīd, dast bi tīgh kard

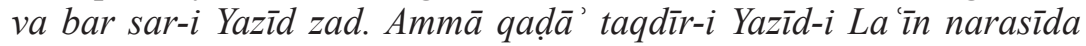
būd hīch kār nakard. Ghawghā barkhāst va chihil nafar-i Yazīd rāa ghulām bi-kusht, āngāhh khud ham kushta shud va ta madām ki Yazìd-i $n \bar{a}-b a-k \bar{a} r$ dar jahān būd hargiz khud khushdil nashud va mardūd-i dìn va dunya büd" "when the servant heard this, he drew his sword and struck Yazid's head. However, he was unsuccessful because the accursed Yazīd's death had not yet been predetermined. Pandemonium ensued as the servant killed 40 of Yazīd's followers; then he, too, was killed, and for as long as Yazīd was alive in this world he was never again happy, and was rejected by both religion and the world").

However, the most important difference relates to an additional part found in both GA (fols: 147-54) and NP (fols: 489-517) (part II). This is the second part of the story, where it dramatically moves on to recount how Muhammad Hanafiyyah, the half-brother of Hassan and Husayn, became determined to avenge their enemies and kill Yazìd. In both GA and NP, part II of the story comes immediately after part I. Interestingly, part II is (clearly) separated from part I in GA by a single phrase, "bāz qișșa az sar bayān kunam" ("Now a new story begins"), which is similar to the phrase al-qișssa (القصة) employed in the Malay $H M H$, which means "the story is that." In NP, while part I finishes with the death of the servant and wanderings of Yazid, part II starts with the heading "Khabar shudan-i Imām Hạīfah va Intiqām az Yazīdi-yān Badbakhtān Giriftan" ("News of Imām Hanīfah and the Revenge on Yazīd's Wretched People"), written in a different hand and with a different paper quality.

In the two manuscripts, part II begins as follows:

- GA: "ān-rūz ki amīr al-mu'minīn shahādat yāft ...chun ghulām [-i amīr al-mu' minīn Husayn] dar Küfa āmad dar ānjā namānd, dar Makka dar-āmad shädiyāna-yi Yazìd mizadand va ān ghulām dar Madīnah dar āmad, ānja ham shādiyāna-yi Yazìd zadand [...]" ("On the day 
of the martyrdom of the Commander of the Believers, ... the servant [of the Commander of the Believers, Husayn] arrived in Kufa and he then left there. He went to Mecca and saw people celebrating Yazīd's [victory], and then the servant went to Medina. There, he also saw that people were celebrating Yazīd's [victory]").

- NP: "al-Qișsa: ammā Husayn rā ghulāmī būd az qadīm [...] ān ghulām 'alam-i adhā rā basta bi-jānib-i Kūfa ravāna gardīd [...] shādiyāna bar-pā kardand [...] az ānjā ravāna-yi Makka-yi mu'azzam gardīd, dar ānjā nīz shādiyāna-hā barpā shud" ("The story is that: Husayn had a servant for years [...] [and] that servant raised the flag of mourning and moved towards Kufa [...] [People] were celebrating there [...] [so] he left and went to Mecca, and there were celebrations there, too $\left.[\ldots]^{\prime \prime}\right)$.

The rest of the story is more or less similar, full of repetitions, in GA and NP. Their part II (which is the last part of the chapter) is also very similar to that of the Malay $H M H$, and ends as follows:

- GA: "[...] Yazīd bugrīkht dar qașr āmad chun Muhammad Hanīfah rā dìd az asp furūd āmad va dar țasht-khāna dar āmad va miyān-i palīdī ghūta khurd. Muhammad Hanīfah rạ̣̄ Allāh 'anhu farmūd tā ātash gardānand va ba 'ọ̄ guyand ki sang-i siyāh shud gird bi gird-i kūh-i Qāf bi-gardad tā Rūz-i Qiyāmat nashusta (?) khāhad būd ba'd az ān fath shud va 'Alī Asghar dar Dimishq va Imām Zayn al-'Ābidīn dar Shām bi-Khilāfat nashāndid" "'Yazīd ran away and went to the castle. When he saw Muhammad Haniffah, he got off his horse and hid in the toilet, becoming covered in filth. Muhammad Hanifah ordered a fire be lit [around him], and some say that he [Yazìd] became like a black stone and will run around the mountain of Qāf, and be unclean until Judgment Day. Then there was conquering and Muhammad Hanīfah appointed as rulers 'Alī Asghar in Damascus and Imām Zayn al- 'Ābidīn in Shām'"). ${ }^{26}$

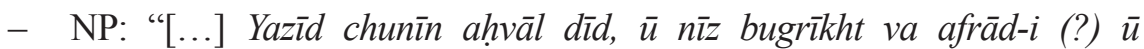
parākanda shudand va jumla az tars-i jān-i khud bi Yazìd bad miguftand. Imām Muhammad Han̄̄fah bi dunbāl-i Yazīd rānd va dar șaf-i mu'minān țabl-i shādī zadand va Yazìd-i nābikār dar khāna dar-āmad. Dar khāna jāy-i qaḍa-yi hajat būd dar ājnā dar āmad, har chand dar khāna $\bar{u}$ rā talab kardan hargiz nayāftand. Imām Muhammad Han̄̄fah farmūd... àtash dar damīd...tā bi khāna-yi $\bar{u}$ àtash girift. Bi qudrat-i Parvardgār Yazìd bi-ṣūrat-i sag-i zard shud va baḍ̄ mī-gūyand bi șürat-i gurg shud va

26. It is odd that both 'Alī Asghar and Zayn al- 'Ābidīn will rule the same regions. This also gave Winstedt the idea that "Zain al- 'Abidin is installed ruler of Damascus in Indo-Malay Muslim fashion, seated on a throne with a Sanskrit name [...]" Winstedt, 1939, p. 107. 

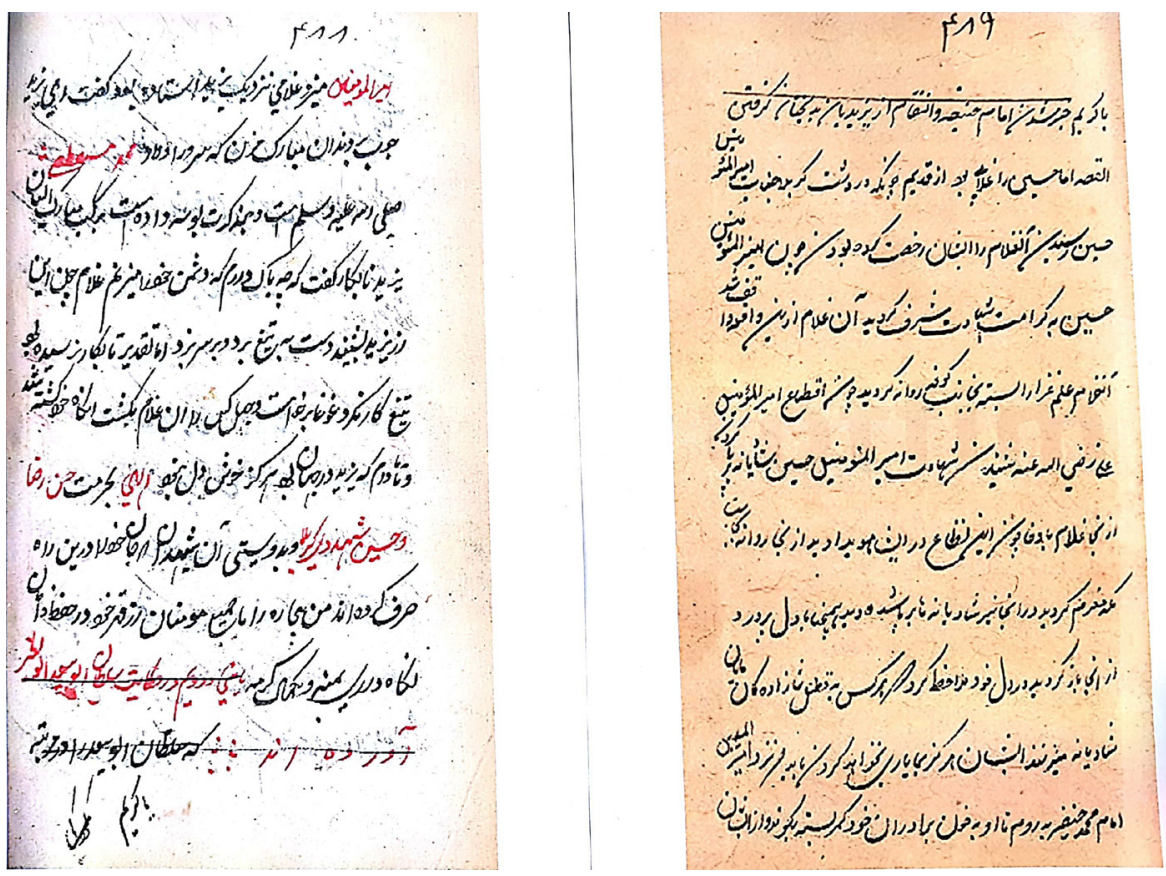

Fig. 2 - From left to right: the end of the part I and the beginning of the part II in NP. The different hands are obvious. Part II starts with the heading "Khabar shudan-i Imām Hanīfah va Intiqām az Yazìdi-ān Badbakhtān Giriftan."

bi-gardāgard-i kūh-i Qāf migardad va tā bi-rūz-i Qiyāmat tashna khāhad būd va 'Al̄̄ Asghar rā bi-khalāfat-i Dimishq nashānd, har yik bi mulk-i khud raft" "'When Yazìd understood the situation, he ran away [...] and his people were scattered, and they all cursed [talked badly about] Yazīd in order to save their lives. Imām Muhammad Ḥanīfah went to find Yazīd. The believers banged drums of joy and the evil Yazīd went into [his] house. There was a toilet into which Yazīd entered. Although they tried hard to find him, they could not. Imām Muhammad Hanīfah ordered a fire be lit [...] and his [Yazìd's] house burnt down. Due to God's will, Yazīd became as a yellow dog, while some say that he became like a wolf and will run around the mountain of Qāf until Judgment Day while suffering terribly from thirst. And [Muḥammad Ḥanīfah] appointed 'Alī Asghar as the ruler of Damascus; everyone went towards his kingdom [...]").

It seems clear that there are two versions of chapter 31 (generally known as "The Story of the Killing of Hassan and Husayn"): (a) the shorter version, part I only, which ends with Yazīd's failure in religion and the world; and (b) the longer version, which includes parts I and II, the latter of which details the 
revenge of Muhammad Hanafiyyah. Due to the existence of variant versions of this chapter, it can be suggested that, although parts I and II are connected, copyists often tried to produce or re-write only part I of the story, in which Muhammad Hanafiyyah does not play any major role. This is obvious in NP: a different writer, with different handwriting and using other paper, added part II into the body of chapter 31 after part I (fig. 2).

\section{Muḥammad Ḥanafiyyah as an Indigenous Spiritual Leader: Challen- ging Hurgronje's Hypothesis}

In MS Malay B 6 (f. 93v) and MS Malay D 5 (f. 49v), both preserved in the British Library, Muhammad Hanafiyyah is said to have been from Boeniara/ Buniara (بنير), which, according to Snouck Hurgronje, is "a subdivision of the Kingdom of Medina" 27 . According to him, Muhammad Hanafiyya of Boeniara was able to kill Yadib (Yazīd). Then, "a small remnant of Yadib's followers took refuge in a cave. At this moment the cave closed of its own accord, and the holy man and his horse are still there, awaiting patiently the day appointed for their resurrection". ${ }^{28}$ However, he does not provide any reference that mentions the name of Boeniara as the residence of Muhammad Hanafiyya. Also, a number of experts I consulted had never heard of the name Boeniara/ Buniara as either a subdivision of Medina or the residence of Muhammad Hanafiyya. Likewise, the earliest Islamic historical sources, such as Ahmad b. Yahyāa al-Balādhurī (d. c. 892 CE), do not have Boeniara as either a subdivision of Medina or Muhammad Hanafiyya's place of residence. In his Ansāb al-Ashrāf (Genealogies of the Nobles), al-Balādhurī opens up new sections dealing with Muhammad Hanafiyya after the story of the killing of Husayn (maqtal al-Husayn b. 'Alī). In these sections, which also include references from Muhammad b. 'Umar al-Wāqidī (d. c. $823 \mathrm{CE}$ ), a well-known early Arab historian, the main cities related to Muhammad Hanafiyya are Medina, which is also his place of death, and al-Baqī', where his grave is located. ${ }^{29}$ Nonetheless, there is a place in Medina called al-Buwayra that, according to Michael Lecker, is related to the "Jewish Naḍir." Apart from the obvious difference between the orthography of al-Buwayra and Boeniara, the map of the markets of Medina on the eve of Islam created by Lecker ${ }^{30}$ as well as the reference by 'Alī b. Ahmad al-Samhūdī's (d. c. 1505) Wafā' al-Wafā' to the house of Muhammad Hanafiyya clearly demonstrate that he was living near

27. C. Snouck Hurgronje, De Atjehers, Leiden \& Batavia, E.J. Brill \& Landsdrukkerij, 1894, vol. 2, p. 180.

28. Ibid.

29. al-Balādhurī, Kitāb Jumal min Ansāb al-Ashrāf, Beirut, Dār al-Fikr, n.d., vol. 3, pp. 395487. There are even disagreements on the birthdate of Muhammad b. al-Hanafiyyah, either thirteen or twenty one years after Hijrah.

30. Michael Lecker, "On the Markets of Medina (Yathrib) in Pre-Islamic and Early Islamic Times," Jerusalem Studies in Arabic and Islam 8, 1986, pp. 133-147. 
"Baqī' al-Gharqad, the cemetery of Medina," close to the Prophet's mosque, and far from al-Buwayra. ${ }^{31}$

However, we should bear in mind that the name of Muhammad Hanafiyya's residence figures prominently in part II of the story, which, according to Brakel, is purely legendary. ${ }^{32}$ Thus, it is highly likely its name will not be found in any historical or traditional sources of Islam. Instead, more attention should be paid to how his residence is introduced in other versions of this story, in different languages.

Islamic epics present a lion-hearted and chivalric image of Muhammad Hanafiyyah, who is displayed as the Imām of his age as well as a messiah. Traces of stories (Pers. Qișas va hikāyatt) dedicated to him can be found in various corners of Western Asia, particularly in the Middle East, in places such as Kharg Island, in Bushehr province or Guilan of Iran, where a tomb ascribed to him (Buq'a-yi Mìr Muhammad-i Hanafiyyah and Imāmzādayi Muhammad-i Hanafiyyah, respectively) is located. ${ }^{33}$ It is said that sailors from South Asia used to visit his tomb on Kharg Island in the Persian Gulf as well. The messianic facet of Muhammad Hanafiyyah has been underscored for many years in the Bamyan Valley of northern Afghanistan, where an area is dedicated to the "dragon slayer" Hazrat-i "Alî. ${ }^{34}$ Local people believed that Emir (Shahzāda) Hanafiyya, the son of 'Alī, is waiting in an underground passageway to reappear and fight for peace, along with his horse and his beloved wife, Bībī Hanīfah. ${ }^{35}$ Indeed, the legends of this region present Muhammad Hanafiyya as al-Mahdī al-muntazar ("The Awaited Mahd $\vec{\imath}$ "), which is an important principle of Twelver Shi 'īsm. Indeed, calling Muhammad Hanafiyya the Mahdi "was initiated by some Shi'ite sects which claimed that he had not died but was only hiding in mountains and which expected his 'second coming' before long." ${ }^{36}$

Following Marc Gaborieau, Calmard says:

the cult and legendary accounts of Muhammad b. Hanafiyya seem to have penetrated into India following the Ghaznavid expedition in the Panjab. A legend centered on Ghāzī Miyān (identified as a certain Sālār Mas ' ūd, a nephew of Maḥmūd of Ghazna) became very popular in Northern India. Ghāzī Miyān becomes a sort of avatar of the "twin" brothers Hassan

31. I am grateful to Michael Lecker for drawing my attention to this point.

32. Brakel (b), p. v.

33. It should be noted that some reports suggest that his grave is located in other places, such as Medina.

34. Jean Calmard, "Mohammad b. al-Hanafiyya dans la religion populaire, le folklore, les légendes dans le monde turco-persan et indo-persan," Cahiers d'Asie centrale 5/6, 1998, pp. 201-220.

35. Ibid.

36. Braginsky 2005, p. 181. The followers of Kaysāniyyah believed that Muhammad b. Hanafiyya is their Imām who is alive and hidden in the mountains of Raḍā, near Medina. W. Madelung, "Kuraybiyya," Encyclopaedia of Islam, 2nd ed., ed. P. Bearman et al., Leiden, Brill, 1979, vol. 5, pp. 433-434. 
and Ḥusayn. Muhammad Ḥanafiyya (or rather Ḥanīfah or Ḥanīf or Ḥambiya Muhammad) appears as avenging his brothers killed by a Hindu raja. ${ }^{37}$

Perhaps unsurprisingly, every author or copyist of the saga of Muhammad Hanafiyya tried to indigenize and present him as one of his own people (e.g., a South Asian or Indian Muslim, a Malay Muslim). As such, the copyist of GA, Shaykh Dawūd Mirdkir, says that the servant of Husayn, upon leaving Medina, decided to visit Muhammad-i Hanīfah, "khalīfa-yi pahlavān-i ākhir al-zamān va shìr-i pāk-i 'älam" ("The Brave Caliph of the End of Time and the Most Chivalric of the Universe"), to inform him of the death of his brother in Karbala. The servant then travelled for three months over a considerable distance before arriving at Muhammad Haniffah's headquarters in the city of Bamyan $^{38}$; In the NP version, copied by Muhammad Sharīf, the son of Mullā Quraysh Ākhund Zādah, ${ }^{39}$ in order to visit "pahlavān-i dīn, Imām al-ashja 'īn" ("The Hero of the Religion, the Leader of the Brave People"), i.e. Imām Muhammad-i Haniffah, the servant sets off for the city of Banil, which refers to the region of Banil Kalle in Pakhtunkhwa, which had been conquered earlier by the Ghaznavids. More importantly, in the Persian manuscript of the British Library, Add. 8149, also previously examined by scholars, the servant travelled to Anbaz(i), a city outside the Arabian Peninsula, to visit Amìr al-Mu'minin Muhammad Hanafiyya. ${ }^{40}$

These points clearly demonstrate the resemblance of the Malay hikayat of Muhammad Hanafiyya (mainly those introduced by Hurgronje) with those of Central and South Asia, and particularly of the Bamyan valley. Furthermore, another Malay version of this story, MS 12377, also preserved in the British Library, suggests the headquarters of Muhammad Hanafiyyah is not Boeniara but another city, one derived from the letters b-n-t-y-a-r:

\section{pergi membawa surat kepada saudaranya ke benua b-n-t-y-a-r}

Whether it reads as Bentara, Bentiar or Bentyar, it is clear that the scribe of this version of $H M H$ did not identify Boeniara as the headquarters of Muhammad Hanafiyya. This signifies that local Malays also tried to indigenize his story. On this subject, it is further possible that the reference to Boeniara in some Malay $H M H$ refers to a district with the same name in Southeast Asia,

37. Marc Gaborieau, "Légende et culte du saint musulman Ghâzî Miyân au Népal occidental et en Inde du Nord," Objets et Mondes 15/3, 1975, pp. 289-310. Jean Calmard, "Popular Literature under the Safavids," in Society and Culture in the Early Modern Middle East: Studies on Iran in the Safavid Period, ed. Andrew J. Newman, Leiden \& Boston, Brill, 2003, pp. 316-339.

38. Or Banyan, which is a title used for Indian merchants who traded between India and the central and southern parts of Persia.

39. There is a city called Akhond Zādah in contemporary Afghanistan.

40. See for example, fl. $28 \mathrm{v}$ and 29. However, further evidence is required to arrive at firm answers in this respect (i.e. Anbaz(i)). 
than to a subdivision in Medina, Arabia. In addition, it might be possible that the name of Boeniara in Java was taken from "a foreign-derived" $H M H .{ }^{41}$

However, as the Safavids (r. 1501-1736) established the Twelver Shī' ì school of Islam as the religion of their empire, storytellers tended to —or had to - produce more works that would decrease and marginalize the messianic and leadership significance of Muhammad Hanafiyya. Thus, on the basis of earlier stories, they produced new or revised older "epico-religious" texts such as the Junayd-näma, and Mukhtār-nāma, among others, in which Muḥammad Hanafiyya is just a warrior while Zayn al- 'Ābidin instead is the main figure of the story, one who is presented as the only Imām of his age ${ }^{42}$, the one who, according to the Safavids, can transfer the genes of 'Alī and Fātimah to the next Shī a Imām.

\section{Analyses}

\section{A Comparison of $\mathrm{HMH}$ and $\mathrm{DMJ}$}

Brakel declared that the structure of both the Persian and the Malay texts is largely similar ${ }^{43}$. Both works include the two main parts of (part I) the Maqtal, on the death of Hassan and Husayn, and (part II) the Hikayat of Muhammad Hanafiyya, which relates the revenge story. As mentioned previously, Brakel used an unspecified Persian manuscript, Add. 8149, dated 1721 AD. In his comparison, he discovered that 9 out of 26 chapters from part I and 19 out of 22 chapters from part II of $H M H$ can be traced back to the Persian text.

In this section, the following will be examined:

- The similarities between $D M J$ and Brakel's $H M H$ found by Brakel in Add. 8149;

- The similarities between $D M J$ and Brakel's $H M H$ NOT found by him in Add. 8149.

This comparison will lead to conclusions in two distinct areas: (a) how far $D M J$ influenced $H M H$; and (b) how this article can build on the work of previous scholars.

As this essay seeks to support previous scholarly work on the origins of $H M H$ it will employ the Romanized and the English versions of $H M H$ produced by Brakel as a composite text, which has elicited some debate among philologists, as well as various other manuscripts. It may be questioned whether the original manuscripts of $H M H$ should be employed in this study. In response to this, it should be noted that I went through the two original Malay $H M H$ that are preserved in the British Library (D5 and B6), and found that, as Brakel himself reported, the aspects found in his critical edition are seen in most other Malay manuscripts. Unfortunately, however, lack of space

41. Personal comm. Edwin Wieringa, 30 January 2018.

42. Jean Calmard, "Popular Literature under the Safavids", 2003, pp. 316-339.

43. Brakel (a), p. 64. 
precludes the inclusion of details from all the Malay manuscripts. Hopefully we will publish a full study on this in the near future.

The main $D M J$ mss. consulted were OL/OP and GA. The OL and OP mss. are the oldest versions of $D M J$ available to me, while the GA ms. provides the most detailed version of the story. In addition, other versions of $D M J$, particularly NP, will be used where it is deemed necessary. Although I wanted to examine whole pages of Add. 8149 - the Persian source examined by Van Ronkel and Brakel - this was not possible ${ }^{44}$; however, this should not pose a problem since OL and OP were copied in 1564 and 1681 AD respectively, i.e. much earlier than Add. 8149.

(A) Similarities between DMJ and HMH on the Basis of Add. 8149

Part I

\begin{tabular}{|c|c|c|c|}
\hline $\begin{array}{l}\text { Brakel's edition } \\
\text { of } H M H\end{array}$ & OL/OP & GA & $\begin{array}{l}\text { Additional } \\
\text { Comments }\end{array}$ \\
\hline $\begin{array}{l}\text { Chapter 2a: } \\
\text { Dahyyat al-Kalb̄̄’s } \\
\text { habit of bringing } \\
\text { fruit to Hassan } \\
\text { and Husayn and } \\
\text { their seeking } \\
\text { fruits in his } \\
\text { sleeves }\end{array}$ & 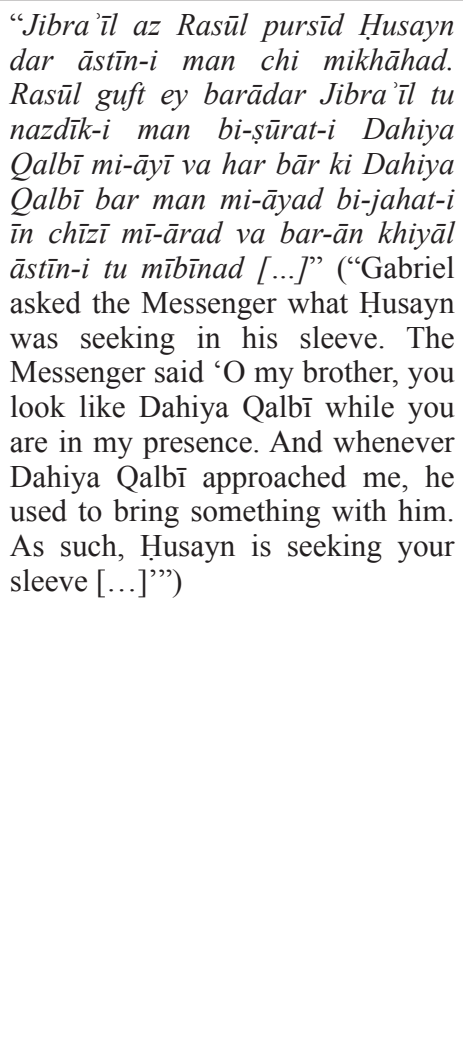 & -- & $\begin{array}{l}\text { With the } \\
\text { exception of GA, } \\
\text { this story is found } \\
\text { in other versions } \\
\text { of this chapter in } \\
D M J \text {, including } \\
\text { NP. } \\
\text { According to the } \\
\text { Malay HMH, } \\
\text { Gabriel brought } \\
\text { a pomegranate } \\
\text { and a grape } \\
\text { from heaven } \\
\text { for Hassan } \\
\text { and Husayn. } \\
\text { However, in } \\
D M J \text { s chapter, } \\
\text { Husayn is the } \\
\text { only grandson } \\
\text { of Muhammad } \\
\text { who seeks the } \\
\text { sleeve of Gabriel, } \\
\text { who brings him a } \\
\text { pomegranate. } \\
\text { Nonetheless, GA } \\
\text { refers to the food } \\
\text { sent to Hassan } \\
\text { and Husayn, via } \\
\text { Gabriel, from } \\
\text { heaven. }\end{array}$ \\
\hline
\end{tabular}

44. I only had the chance to examine parts of this manuscript. Following other scholars, I will rely on Brakel who went through Add. 8149 completely. 


\begin{tabular}{|c|c|c|c|}
\hline $\begin{array}{l}\text { Brakel's edition } \\
\text { of } H M H\end{array}$ & OL/OP & GA & $\begin{array}{l}\text { Additional } \\
\text { Comments }\end{array}$ \\
\hline $\begin{array}{l}\text { Chapter } 2 \text { b: } \\
\text { Hassan's and } \\
\text { Husayn's interest } \\
\text { in wearing } \\
\text { the feast-day } \\
\text { garments and how } \\
\text { the Prophet gave } \\
\text { them what they } \\
\text { wanted. Later, } \\
\text { the green one } \\
\text { was chosen for } \\
\text { Hassan and red } \\
\text { one for Husayn. }\end{array}$ & 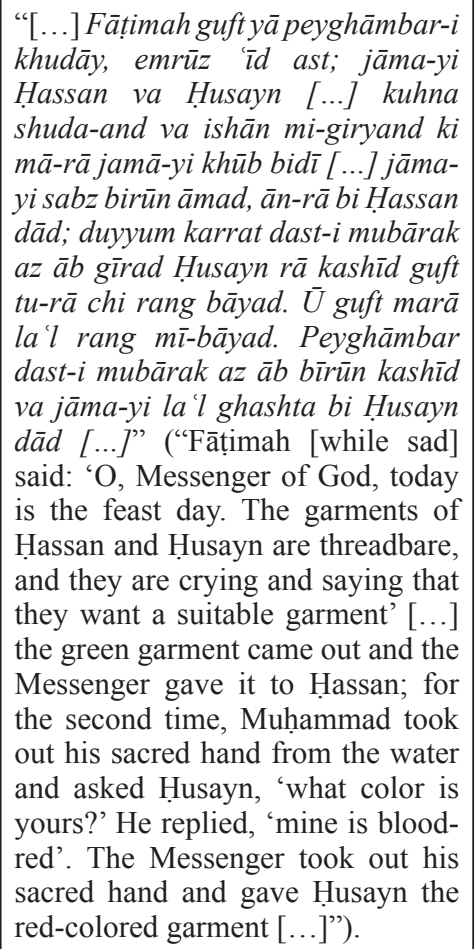 & -- & $\begin{array}{l}\text { This story is } \\
\text { seen in other } \\
\text { Persian versions, } \\
\text { including NP. } \\
\text { Unlike the } \\
\text { Persian version, } \\
\text { the Malay } \\
\text { HMH says that } \\
\text { Muhammad } \\
\text { received two } \\
\text { garments for } \\
\text { Hassan and } \\
\text { Husayn from a } \\
\text { chest brought by } \\
\text { Gabriel. } \\
\text { However, in GA, } \\
\text { it is Gabriel who } \\
\text { pours green onto } \\
\text { the handbook (?) } \\
\text { of Hassan (sabz } \\
\text { bar takhta-yi } \\
\text { Hassan) and ruby } \\
\text { red onto that of } \\
\text { Husayn (Yāqūt- } i \\
\text { surkh bar takhta- } \\
\text { yi Husayn) }\end{array}$ \\
\hline $\begin{array}{l}\text { Chapter 2c: } \\
\text { an angel with } \\
\text { burnt wings sat } \\
\text { on Gabriel's } \\
\text { shoulder; Hassan } \\
\text { and Husayn } \\
\text { rubbed her } \\
\text { shoulders; thus, } \\
\text { she was healed } \\
\text { and could fly } \\
\text { away. }\end{array}$ & 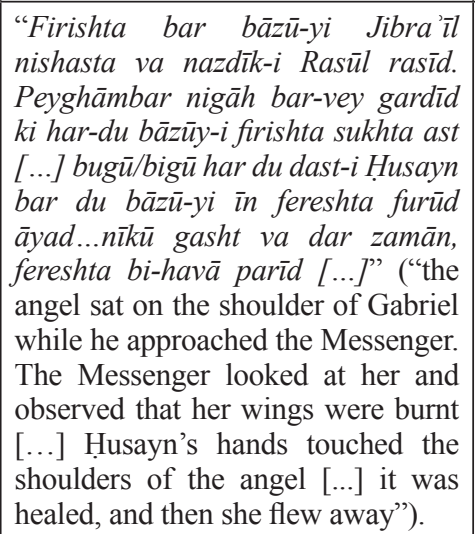 & -- & $\begin{array}{l}\text { This story is } \\
\text { seen in other } \\
\text { Persian versions, } \\
\text { including NP. } \\
\text { In contrast to the } \\
\text { Malay version, } \\
\text { which says that } \\
\text { Hassan and } \\
\text { Husayn touched } \\
\text { the shoulder } \\
\text { of the angel, } \\
\text { Persian texts only } \\
\text { mention the name } \\
\text { of Husayn. }\end{array}$ \\
\hline
\end{tabular}




\begin{tabular}{|c|c|c|c|}
\hline $\begin{array}{c}\text { Brakel's edition } \\
\text { of } H M H\end{array}$ & OL/OP & GA & $\begin{array}{l}\text { Additional } \\
\text { Comments }\end{array}$ \\
\hline $\begin{array}{l}\text { Chapter 3: The } \\
\text { Prophet gave a } \\
\text { bottle with earth } \\
\text { in it to Ummi } \\
\text { Salamah }\end{array}$ & 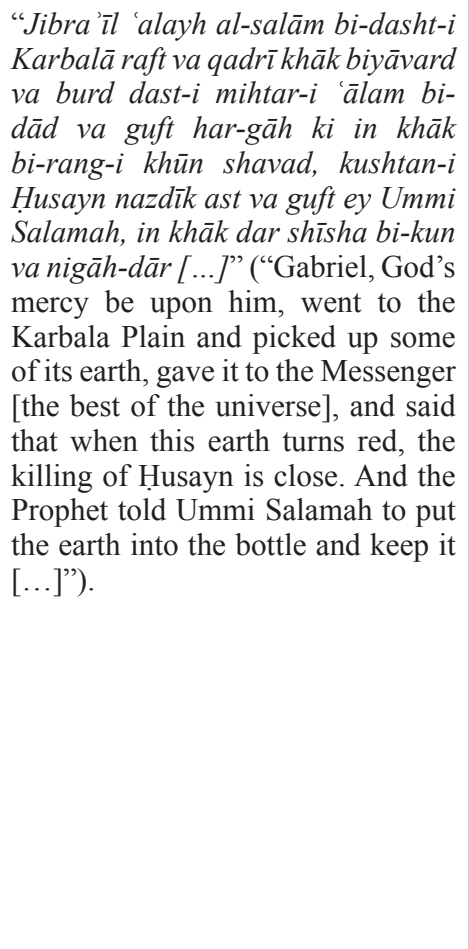 & 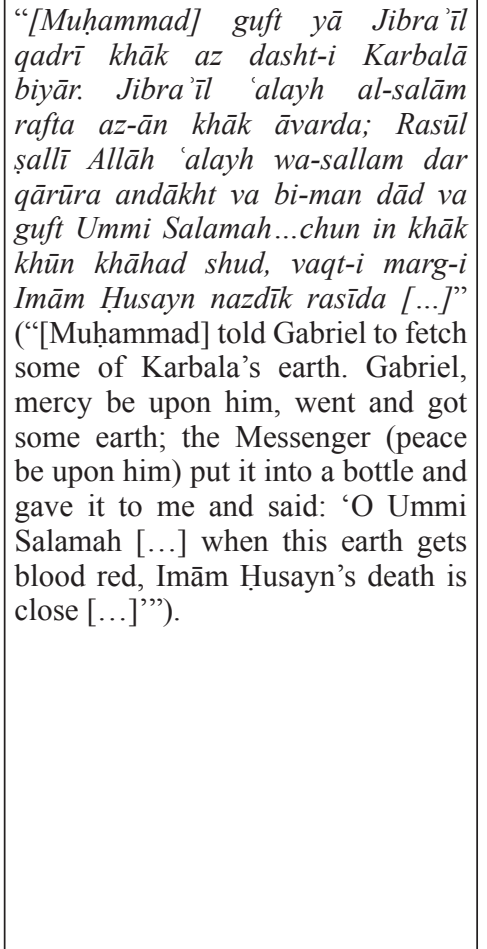 & $\begin{array}{l}\text { Other Persian } \\
\text { manuscripts } \\
\text { express the story } \\
\text { as do OL/OP. } \\
\text { In both GA } \\
\text { and the Malay } \\
\text { HMH, this story } \\
\text { is prefaced with } \\
\text { the Prophet's } \\
\text { concern about } \\
\text { the loneliness } \\
\text { of Hassan and } \\
\text { Husayn at the } \\
\text { time of their } \\
\text { deaths. In this } \\
\text { regard, the GA } \\
\text { version says that } \\
\text { Muhammad said: } \\
\text { "vāy Hassan } \\
\text { vay Husayn; } \\
\text { vāy gharībān; } \\
\text { vāy yatimāan" } \\
\text { ("Poor Hassan, } \\
\text { poor Husayn; my } \\
\text { two poor lonely } \\
\text { children, my poor } \\
\text { orphans"). }\end{array}$ \\
\hline $\begin{array}{l}\text { Chapter 4: } \\
\text { Mu'āwiya's } \\
\text { (unsuccessful) } \\
\text { attempt not to } \\
\text { have intercourse } \\
\text { with a woman } \\
\text { and "to remain } \\
\text { childless," as per } \\
\text { Muhammad's } \\
\text { recommendation, } \\
\text { is seen after he } \\
\text { was bitten by a } \\
\text { scorpion. }\end{array}$ & 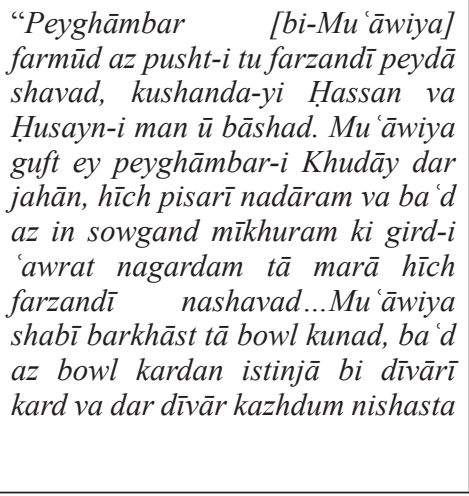 & 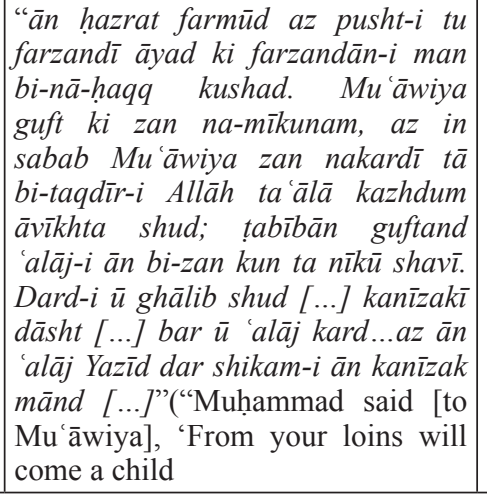 & $\begin{array}{l}\text { Brakel said that } \\
\text { he could not find } \\
\text { a parallel for "the } \\
\text { birth of Yazīd" } \\
\text { in Add. } 8149^{*} \text {. } \\
\text { However, all } \\
\text { available Persian } \\
\text { versions of } D M J \\
\text { have the story } \\
\text { from OL/OP. } \\
\text { Furthermore, } \\
\text { intercourse with a } \\
\text { slave is found }\end{array}$ \\
\hline
\end{tabular}

\footnotetext{
* Brakel (a), p. 7.
} 


\begin{tabular}{|c|c|c|c|}
\hline $\begin{array}{c}\text { Brakel's edition } \\
\text { of } \boldsymbol{H M H}\end{array}$ & OL/OP & GA & $\begin{array}{l}\text { Additional } \\
\text { Comments }\end{array}$ \\
\hline & 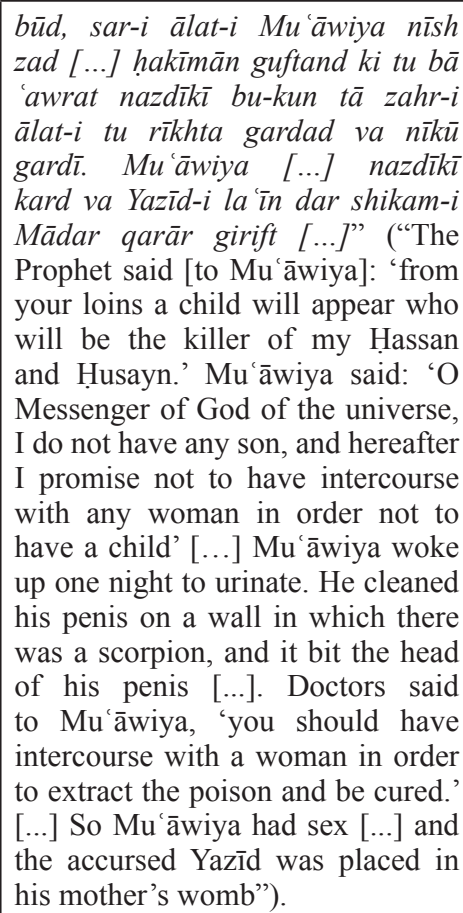 & $\begin{array}{l}\text { who will unjustly kill my children.' } \\
\text { Thus, Mu 'âwiya did not get married } \\
\text { until, in accordance with the divine } \\
\text { predestination of God Almighty, } \\
\text { he was bitten by a scorpion, and } \\
\text { doctors said that his healing would } \\
\text { depend on him finding a wife. His } \\
\text { pain increased [...] he had a female } \\
\text { slave [...] she became his healing } \\
{[\ldots] \text { [and], from that intercourse, }} \\
\text { Yazīd was placed in the womb of } \\
\text { that female slave"). }\end{array}$ & $\begin{array}{l}\text { in HMH: "Tabib } \\
\text { berketa: Hay } \\
\text { Mu'awiyah! } \\
\text { Jika tiada } \\
\text { engkau kepada } \\
\text { perempuan, } \\
\text { tiadakan sembuh } \\
\text { penyakit itu! } \\
\text { [...] Maka } \\
\text { daripada sangat } \\
\text { tiada menderita } \\
\text { sakitnya, maka } \\
\text { disuruhnya } \\
\text { cahari seorang } \\
\text { perempuan tuha } \\
\text { lagi Habsi [...]" } \\
\text { (p. 124). See the } \\
\text { discussion in the } \\
\text { final section of } \\
\text { this article. }\end{array}$ \\
\hline $\begin{array}{l}\text { Chapter 21: } \\
\text { (a) Yazīd's } \\
\text { desire to marry } \\
\text { 'Abdullah } \\
\text { Zubair's wife } \\
\text { "who was } \\
\text { particularly } \\
\text { beautiful" } \\
\text { (b) Mu'āwiya's } \\
\text { suggestion to } \\
\text { 'Abdullah Zubair } \\
\text { that he gives his } \\
\text { former's daughter } \\
\text { to 'Abdullah } \\
\text { Zubair and the } \\
\text { latter becomes the } \\
\text { ruler of Egypt. }\end{array}$ & 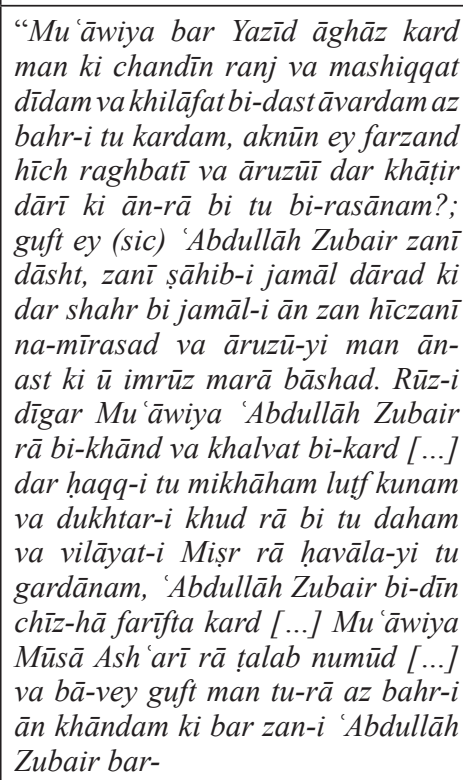 & 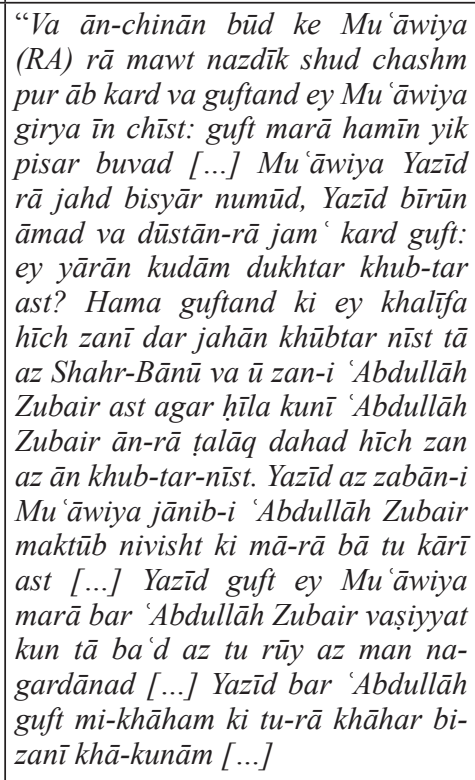 & $\begin{array}{l}\text { This story is } \\
\text { found in other } \\
\text { versions of } D M J \text {. } \\
\text { However, the } \\
\text { GA version } \\
\text { introduces the } \\
\text { wife of 'Abdullāh } \\
\text { Zubair as Shahr- } \\
\text { Bānū. Moreover, } \\
\text { GA tries to } \\
\text { excuse Mu'āwiya } \\
\text { and ascribes the } \\
\text { cuckolding of } \\
\text { 'Abdullāh Zubair } \\
\text { to Yazīd. }\end{array}$ \\
\hline
\end{tabular}




\begin{tabular}{|c|c|c|c|}
\hline $\begin{array}{l}\text { Brakel's edition } \\
\text { of } \boldsymbol{H M H}\end{array}$ & OL/OP & GA & $\begin{array}{l}\text { Additional } \\
\text { Comments }\end{array}$ \\
\hline $\begin{array}{l}\text { (c) Mu'āwiya } \\
\text { sent Mūsa Ash 'arī } \\
\text { to the wife of } \\
\text { 'Abdullāh Zubair, } \\
\text { to propose his son } \\
\text { to her. } \\
\text { (d) The wife } \\
\text { of 'Abdullāh } \\
\text { Zubair rejected } \\
\text { Yazīd and } \\
\text { instead accepted } \\
\text { Husayn's } \\
\text { proposal, who, } \\
\text { according to } \\
\text { Mūsā Ash'arī, } \\
\text { also wanted her. }\end{array}$ & 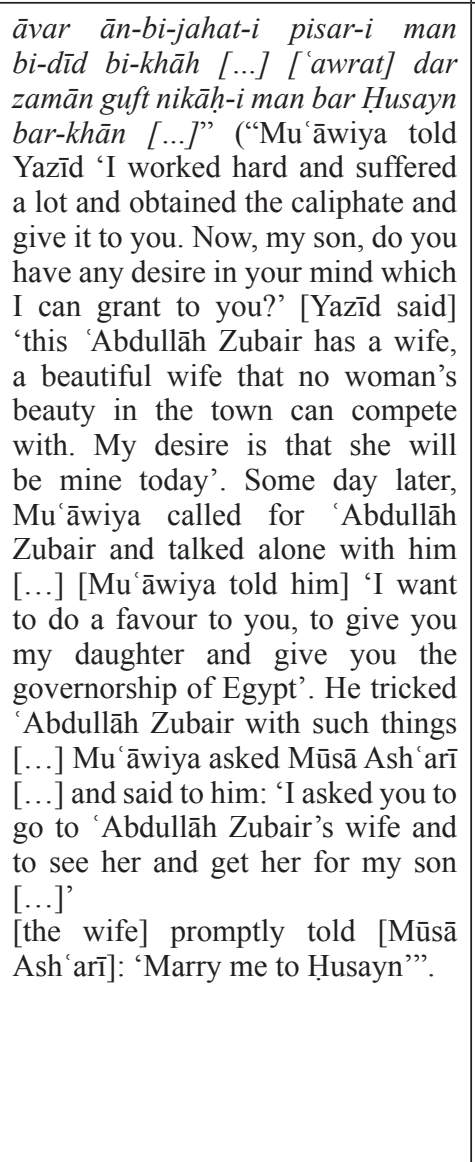 & 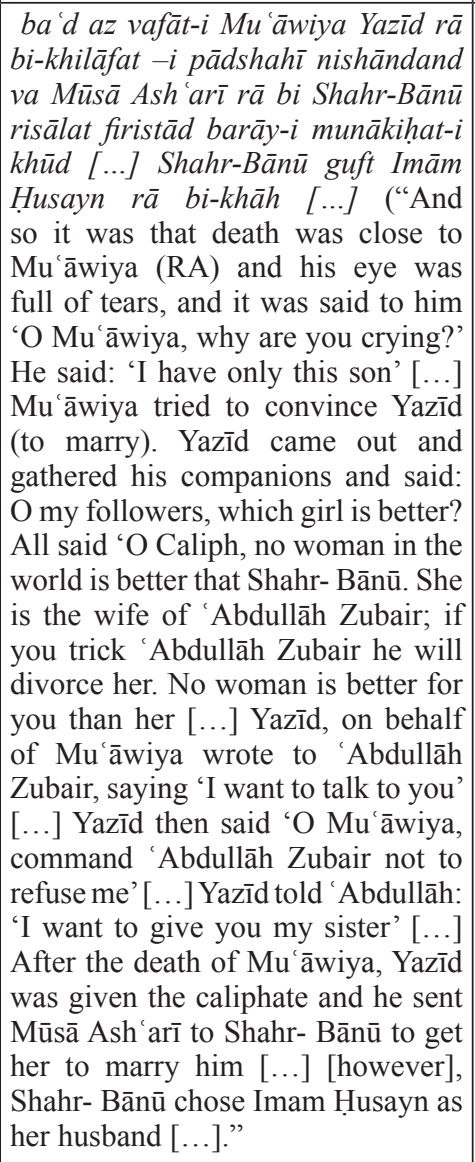 & \\
\hline $\begin{array}{l}\text { Chapter 22: } \\
\text { (a) Mu'āwiya } \\
\text { dies } \\
\text { (b) Yazīd asks the } \\
\text { leader of Medina } \\
\text { to kill Hassan and } \\
\text { Husayn; "[he] } \\
\text { replied that he } \\
\text { was not capable } \\
\text { of fighting openly } \\
\text { against Husayn". }\end{array}$ & 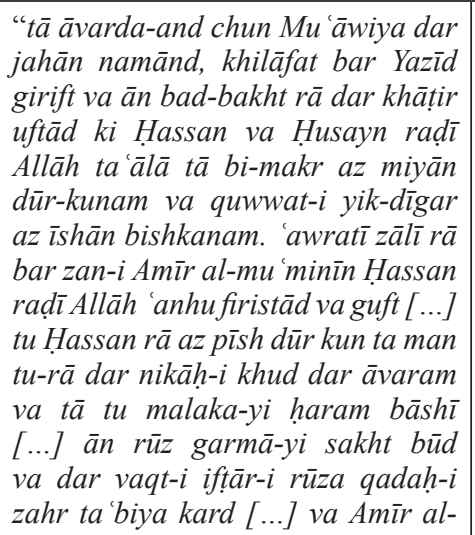 & 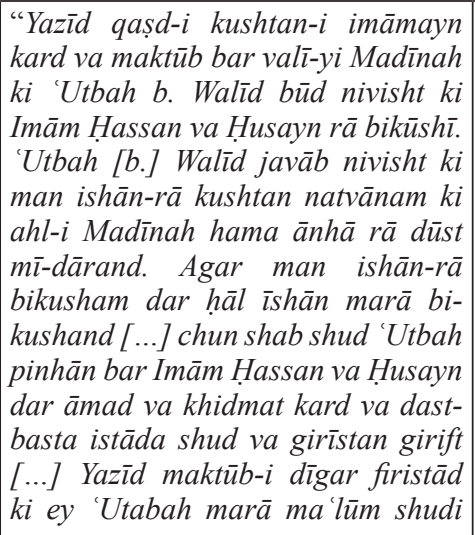 & $\begin{array}{l}\text { According to both } \\
\text { Malay } H M H \text { and } \\
\text { Persian stories of } \\
D M J \text {, Yazid tried } \\
\text { to kill Hassan } \\
\text { and Husayn after } \\
\text { the death of his } \\
\text { father, Mu 'āwiya. } \\
\text { OP's story } \\
\text { resembles that of } \\
\text { NP, too. }\end{array}$ \\
\hline
\end{tabular}




\begin{tabular}{|c|c|c|c|}
\hline $\begin{array}{c}\text { Brakel's edition } \\
\text { of } H M H\end{array}$ & OL/OP & GA & $\begin{array}{l}\text { Additional } \\
\text { Comments }\end{array}$ \\
\hline $\begin{array}{l}\text { (c) persuades } \\
\text { Hassan's wife } \\
\text { to kill him with } \\
\text { poison "with the } \\
\text { promise that he } \\
\text { would marry her } \\
\text { and make her a } \\
\text { ruler". } \\
\text { (d) Hassan is } \\
\text { killed when he } \\
\text { breaks his fast } \\
\text { with the poisoned } \\
\text { water. } \\
\text { (e) Before his } \\
\text { death, Hassan } \\
\text { asks Husayn to } \\
\text { "bury him by } \\
\text { the tomb of the } \\
\text { Envoy!", which is } \\
\text { refused by Yazīd. } \\
\text { (f) 'Abdullāh } \\
\text { Mas 'ūd } \\
\text { intervenes and } \\
\text { does not allow } \\
\text { Husayn to attack } \\
\text { Yazīd, because } \\
\text { Husayn was "the } \\
\text { only surviving } \\
\text { descendant of the } \\
\text { Prophet" }\end{array}$ & 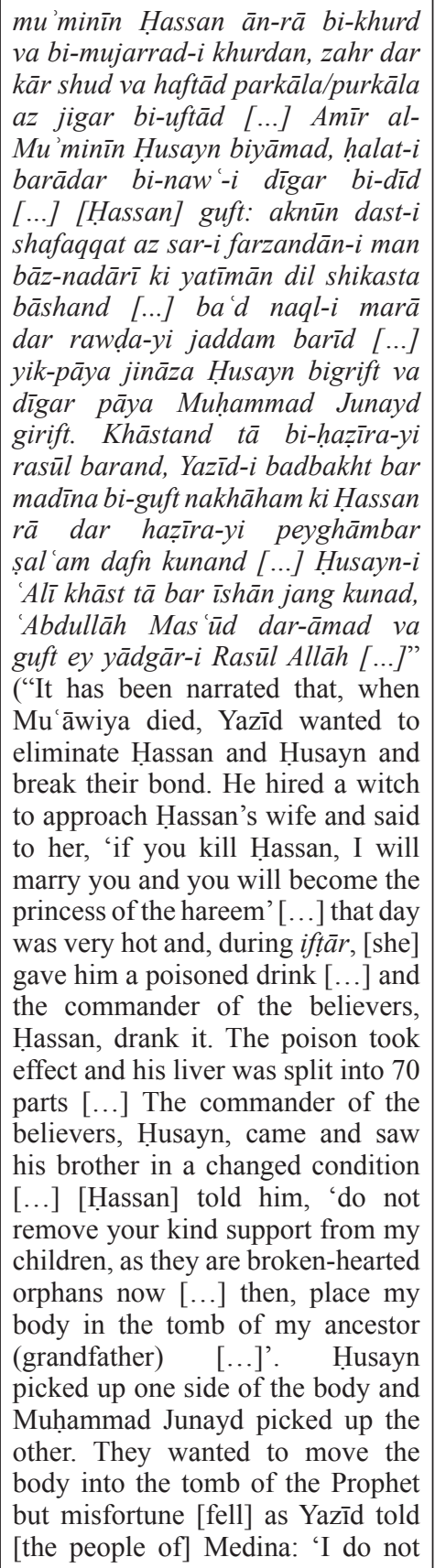 & 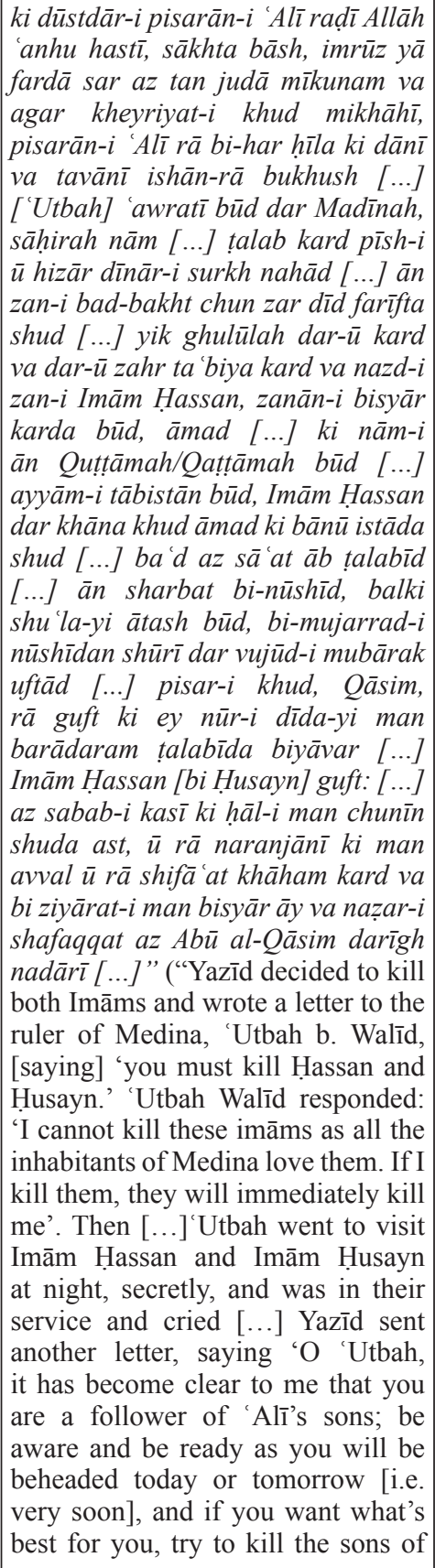 & $\begin{array}{l}\text { It is clear that the } \\
\text { different stories } \\
\text { outlined in } H M H \\
\text { on the death of } \\
\text { Hassan are seen } \\
\text { in both OP and } \\
\text { GA. } \\
\text { In other Persian } \\
\text { manuscripts of } \\
\text { DMJ (e.g. Ms. } \\
853 \text { in Michigan), } \\
\text { the name of } \\
\text { Hassan's wife } \\
\text { is mentioned as } \\
\text { Asmā, which } \\
\text { is the case } \\
\text { according to most } \\
\text { Islamic traditions. } \\
\\
\text { Unlike both } \\
\text { Persian and } \\
\text { Malay stories, } \\
\text { Sh'̄' í traditions } \\
\text { suggest that } \\
\text { Qutțāmah is the } \\
\text { one who tempted } \\
\text { Ibn Muljam to } \\
\text { kill 'Alī b. Abī } \\
\text { TTālib. } \\
\end{array}$ \\
\hline
\end{tabular}




\begin{tabular}{|c|c|c|c|}
\hline $\begin{array}{c}\text { Brakel's edition } \\
\text { of } H M H\end{array}$ & OL/OP & GA & $\begin{array}{l}\text { Additional } \\
\text { Comments }\end{array}$ \\
\hline & $\begin{array}{l}\text { permit you to bury Hassan in the } \\
\text { tomb of the Messenger (peace be } \\
\text { upon him) [...]'. Husayn went to } \\
\text { fight them, but 'Abdullāh Mas 'udd } \\
\text { intervened and said: 'O the only } \\
\text { memory of the Messenger of God } \\
{[\ldots] \text { '"). }}\end{array}$ & 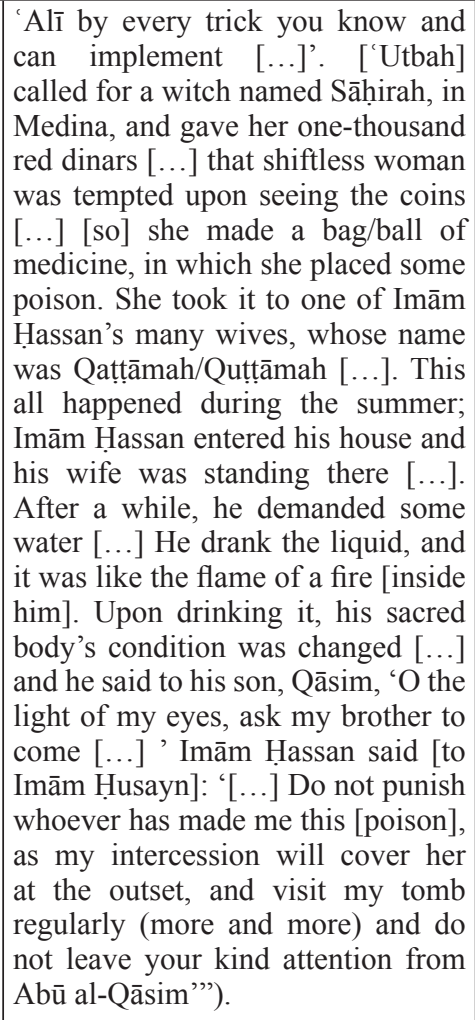 & \\
\hline $\begin{array}{l}\text { Chapter 23: } \\
\text { (a) "Yazīd sent } \\
\text { a letter to Utbah } \\
\text { [...] in which he } \\
\text { informed him } \\
\text { that all the Arabs } \\
\text { had already paid } \\
\text { homage to him } \\
\text { as Caliph. When } \\
\text { Utbah conveyed } \\
\text { the letter to } \\
\text { Husayn, the latter } \\
\text { became enraged } \\
\text { and wondered } \\
\text { whether the Arabs } \\
\text { had perhaps } \\
\text { forgotten that } \\
\text { the Prophet had } \\
\text { destined Yazid for } \\
\text { Hell." }\end{array}$ & 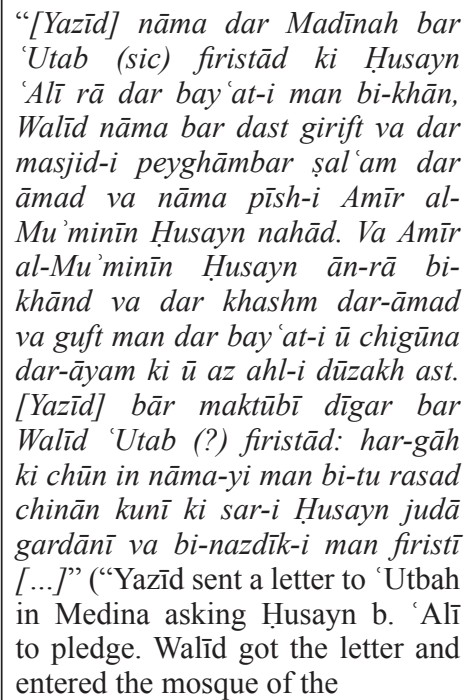 & 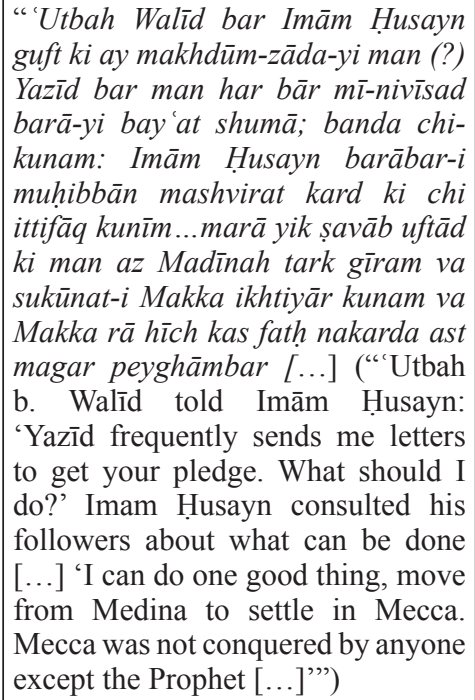 & $\begin{array}{l}\text { The resemblance } \\
\text { between } D M J \\
\text { OL/OP and the } \\
\text { Malay versions } \\
\text { are more obvious } \\
\text { than in the GA } \\
\text { copy. }\end{array}$ \\
\hline
\end{tabular}




\begin{tabular}{|c|c|c|c|}
\hline $\begin{array}{l}\text { Brakel's edition } \\
\text { of } H M H\end{array}$ & OL/OP & GA & $\begin{array}{l}\text { Additional } \\
\text { Comments }\end{array}$ \\
\hline $\begin{array}{l}\text { (b) "Yazīd asked } \\
\text { Utbah to bring } \\
\text { him Husayn's } \\
\text { head in return for } \\
\text { a reward." }\end{array}$ & $\begin{array}{l}\text { Prophet (peace be upon him) and } \\
\text { placed the letter before Husayn. } \\
\text { The Commander of the Believers } \\
\text { Husayn read the letter and became } \\
\text { enraged and said, 'how can I pledge } \\
\text { with Yazīd when he is one of the } \\
\text { people of Hell?' Yazīd sent another } \\
\text { letter to 'Utbah b. Walīd [saying]: } \\
\text { When you get this letter of mine, } \\
\text { chop off the head of Husayn and } \\
\text { bring it to me [....'”') }\end{array}$ & & \\
\hline $\begin{array}{l}\text { Chapter 24: } \\
\text { (a) Shamīr } \\
\text { (Simir) went } \\
\text { forward to behead } \\
\text { Husayn; } \\
\text { (b) [Emir] } \\
\text { Husayn asked } \\
\text { him to show his } \\
\text { chest } \\
\text { (c) Shamīr's chest } \\
\text { was black and he } \\
\text { had the nipples of } \\
\text { a dog } \\
\text { (d)Husayn } \\
\text { recalled the } \\
\text { Prophet's } \\
\text { statement about } \\
\text { his killer's } \\
\text { physical features; }\end{array}$ & 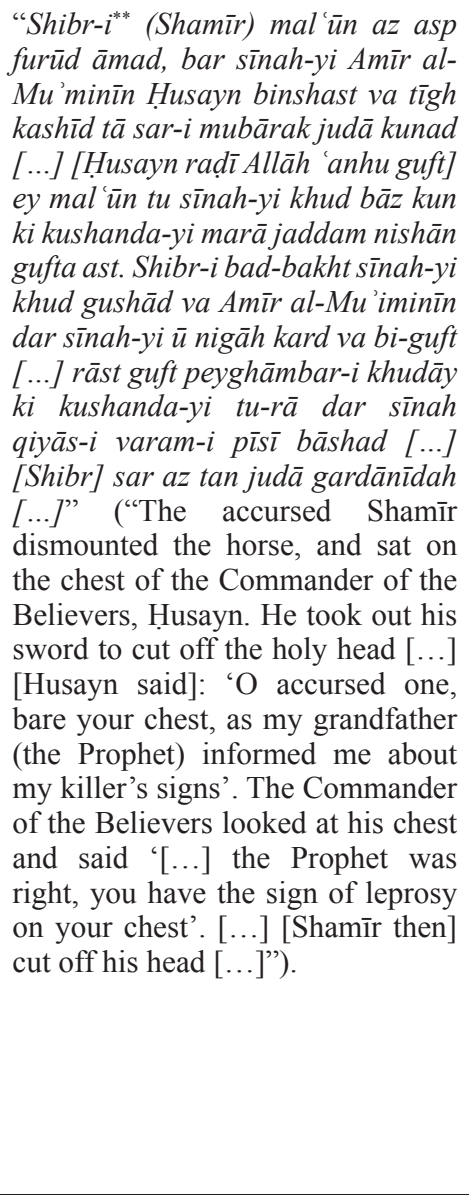 & 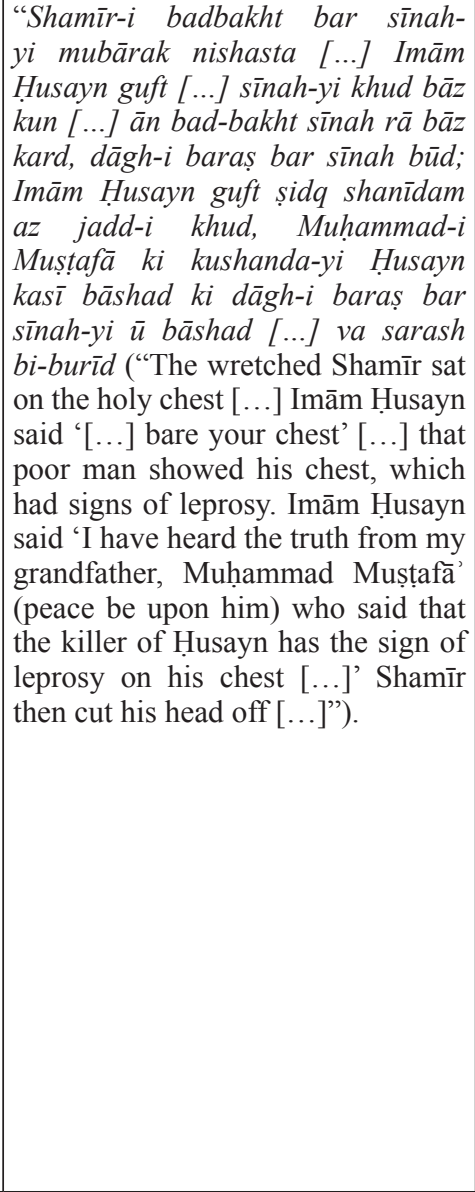 & $\begin{array}{l}\text { The death scene } \\
\text { of Husayn in } \\
H M H \text { largely } \\
\text { resembles that in } \\
D M J . \\
\text { Although none } \\
\text { of the available } \\
\text { versions of } D M J \\
\text { mention that } \\
\text { Shamīr had the } \\
\text { nipples of a dog, } \\
\text { the only available } \\
\text { Persian document } \\
\text { frequently copied } \\
\text { from the 16th to } \\
\text { 19th centuries } \\
\text { is "The Garden } \\
\text { of the Martyrs" } \\
\text { ("Rawdit al- } \\
\text { Shuhadā'") } \\
\text { (c. } 1503 \text { ), the } \\
\text { magnum opus } \\
\text { of Kamāl al- } \\
\text { Dīn Hiusayn } \\
\text { Wā' 'iz Kāshifĩ. } \\
\text { According to this } \\
\text { work, Husayn } \\
\text { observed that } \\
\text { Shamīr's teeth } \\
\text { had turned into } \\
\text { those of a pig } \\
\text { and that his chest } \\
\text { was afflicted with } \\
\text { leprosy***. }\end{array}$ \\
\hline
\end{tabular}

** The name of Shamīr was written as Shibr in the Abū Muslim-nāma, too. See Jean Calmard, "Popular Literature under the Safavids", 2003, p. 318.

***Kamāl al-Dīn Husayn Wā'iz Kāshifī, Rawḍtat al-Shuhadā', Lucknow, Munshi Newal Kishore, 1873. 


\begin{tabular}{|c|c|c|c|}
\hline $\begin{array}{c}\text { Brakel's edition } \\
\text { of } H M H\end{array}$ & OL/OP & GA & $\begin{array}{l}\text { Additional } \\
\text { Comments }\end{array}$ \\
\hline $\begin{array}{l}\text { Chapter 25: } \\
\text { (a) Upon the } \\
\text { death of Husayn, } \\
\text { Ja far the son of } \\
\text { Abū Bakar stayed } \\
\text { in Mecca where } \\
\text { he performed the } \\
\text { tawäf. There he } \\
\text { saw a masked } \\
\text { man who was } \\
\text { seeking God's } \\
\text { forgiveness as he } \\
\text { had wanted to get } \\
\text { the jewel on the } \\
\text { belt of Hiusayn's } \\
\text { corpse. } \\
\text { (b) He cut off } \\
\text { both Husayn's } \\
\text { hands; then he } \\
\text { heard a voice. } \\
\text { (c) Angels } \\
\text { washed Ḥusayn's } \\
\text { corpse. } \\
\text { (d) The } \\
\text { appearance of } \\
\text { Noah, Abraham, } \\
\text { Ismail, Miriam, } \\
\text { Eva, Sarah, } \\
\text { Hagar, and Isaac. }\end{array}$ & 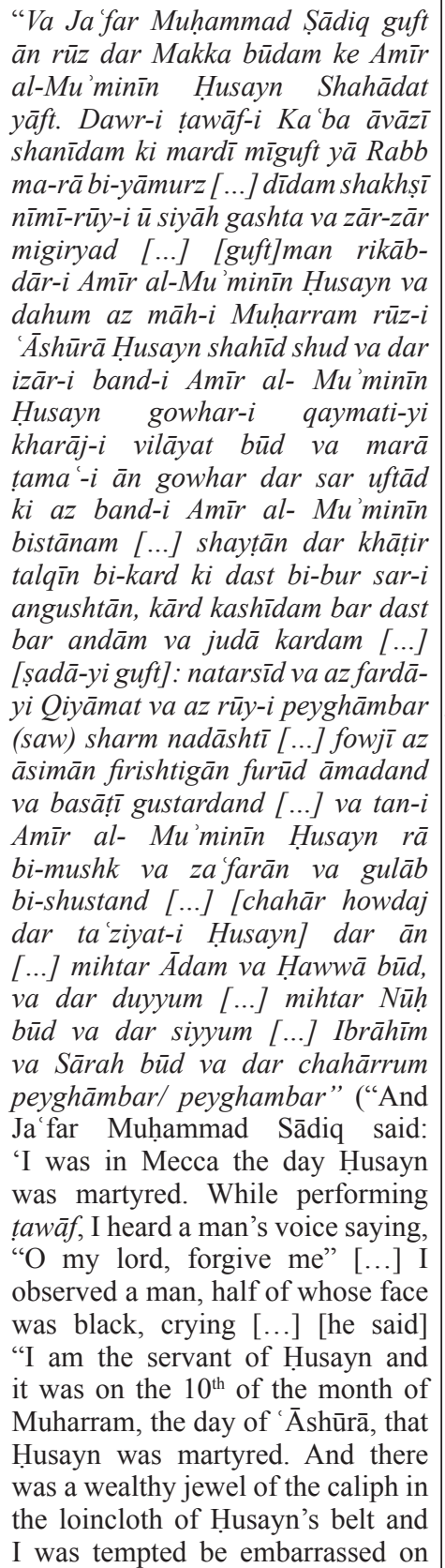 & 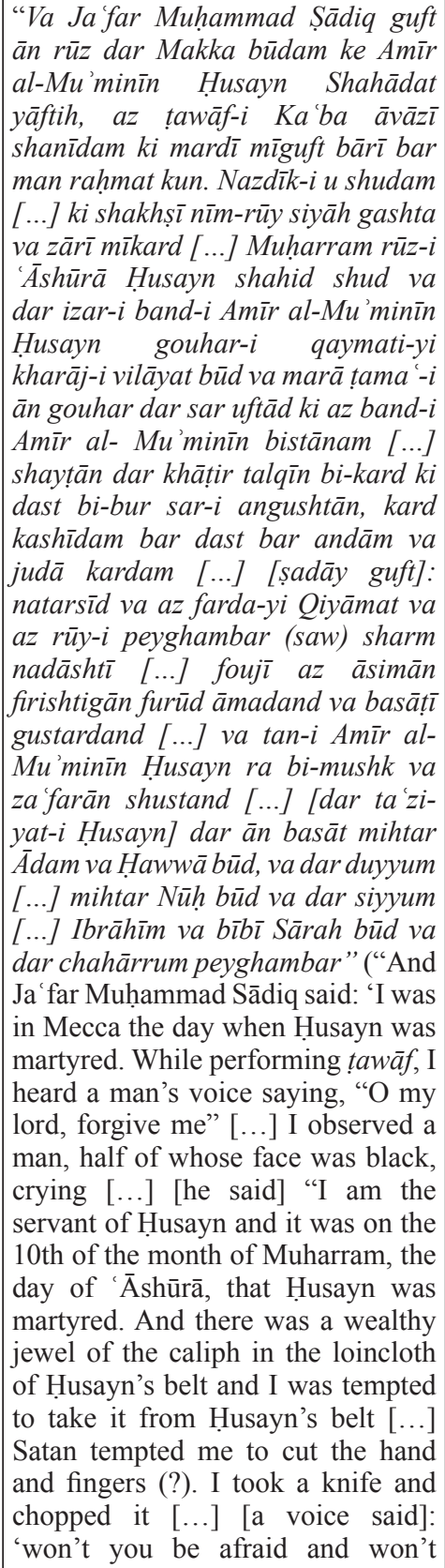 & $\begin{array}{l}\text { This story is } \\
\text { found in almost } \\
\text { every version of } \\
D M J \text {. } \\
\text { As Brakel says: } \\
\text { Ja far bin Abī } \\
\text { Bakar in the } \\
\text { Malay text is } \\
\text { "of course a } \\
\text { corruption of } \\
\text { Ja'far as-Sadiq } \\
\text { b. Muhammad } \\
\text { al-Bakir (the } \\
\text { famous Imam), as } \\
\text { confirmed by the } \\
\text { Persian account" } \\
\text { of Add. } 8149 \\
\text { and other DMJ } \\
\text { versions. }\end{array}$ \\
\hline
\end{tabular}




\begin{tabular}{|c|c|c|c|}
\hline $\begin{array}{l}\text { Brakel's edition } \\
\text { of } \boldsymbol{H M H}\end{array}$ & OL/OP & GA & $\begin{array}{l}\text { Additional } \\
\text { Comments }\end{array}$ \\
\hline & $\begin{array}{l}\text { to take it from Husayn's belt }[\ldots] \\
\text { Satan tempted me to cut the hand } \\
\text { and fingers (?). I took a knife and } \\
\text { chopped it [...] [a voice said]: } \\
\text { 'won't you be afraid and won't you } \\
\text { the Day of Judgment when facing } \\
\text { the Prophet?' [...] a group of angels } \\
\text { came down from heaven and began } \\
\text { a feast [...] and washed the corpse } \\
\text { of Husayn with mushk and saffron } \\
\text { and rosewater [four howdah come } \\
\text { to commemorate his death]. At this } \\
\text { event Prophet Adam and Hawwa, } \\
\text { second Noah, third Abraham and } \\
\text { Sarah, and fourth the Prophet } \\
\text { himself were in attendance"). }\end{array}$ & $\begin{array}{l}\text { you be embarrassed on the Day } \\
\text { of Judgment when facing the } \\
\text { Prophet?' [...] a group of angels } \\
\text { came down from heaven and began } \\
\text { a feast }[\ldots] \text { and washed the corpse } \\
\text { of Husayn with mushk and saffron } \\
\text { [to commemorate his death]. At that } \\
\text { event Prophet Adam and Hawwa, } \\
\text { second Noah, third Abraham and } \\
\text { bibi Sarah and fourth the Prophet } \\
\text { himself were in attendance"). }\end{array}$ & \\
\hline $\begin{array}{l}\text { Chapter 26: } \\
\text { (a) Angels, along } \\
\text { with Adam, } \\
\text { Khadija, Fatimah, } \\
\text { and Mary paid the } \\
\text { final honours to } \\
\text { Husayn's corpse. } \\
\text { (b) The women } \\
\text { in Husayn's army } \\
\text { were captured by } \\
\text { Yazīd's army. } \\
\text { (c) A believer in } \\
\text { Damascus left } \\
\text { the city and saw } \\
\text { the women of the } \\
\text { Prophet's family } \\
\text { having their veils } \\
\text { removed. } \\
\text { (d) The believer } \\
\text { introduced } \\
\text { himself as Saleh. }\end{array}$ & 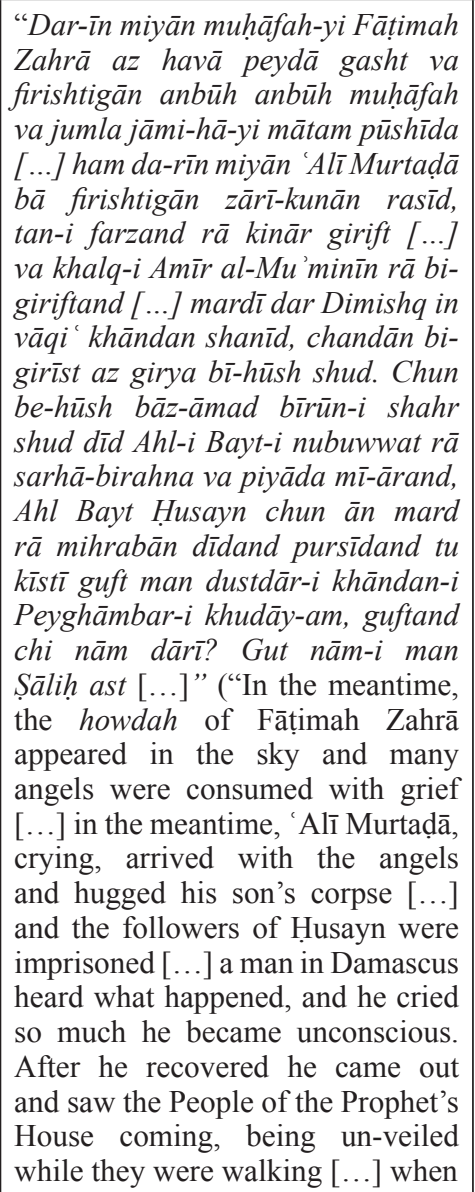 & 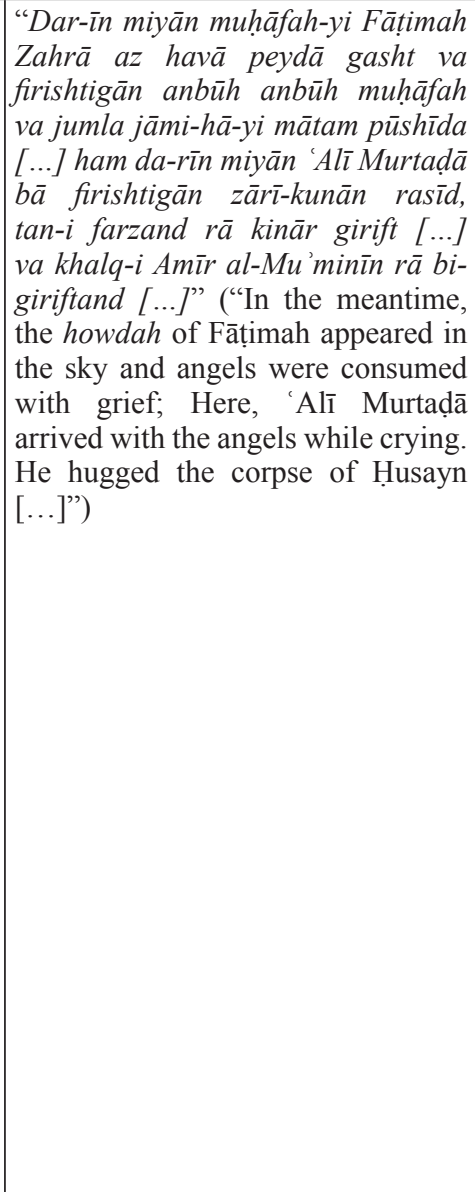 & $\begin{array}{l}\text { Although GA } \\
\text { is silent on the } \\
\text { role of Saālih, NP } \\
\text { presents it as very } \\
\text { similar to that } \\
\text { in other } D M J \text { 's } \\
\text { as well as Add. } \\
8149 \text { and Malay } \\
H M H \text { s. } \\
\text { In most } D M J \\
\text { versions, } \\
\text { following the } \\
\text { incarceration of } \\
\text { Husayn's family } \\
\text { the story of a } \\
\text { monk who was } \\
\text { asked to hold the } \\
\text { head of Husayn } \\
\text { overnight is told, } \\
\text { which is also } \\
\text { not in the Malay } \\
\text { edition of Brakel. }\end{array}$ \\
\hline
\end{tabular}




\begin{tabular}{|l|l|l|l|}
\hline $\begin{array}{c}\text { Brakel's edition } \\
\text { of } \boldsymbol{H M H}\end{array}$ & \multicolumn{1}{c|}{ OL/OP } & GA & $\begin{array}{c}\text { Additional } \\
\text { Comments }\end{array}$ \\
\hline & $\begin{array}{l}\text { the Household of Husayn found } \\
\text { the man they asked him: 'Who } \\
\text { are you?'He replied that he was a } \\
\text { friend of the family of the Prophet } \\
\text { of Islam. They asked, 'what is your } \\
\text { name?' He said, 'my name is Sălih } \\
{[\ldots] \text { ]") }}\end{array}$ & & \\
\hline
\end{tabular}

As such, it can be said that all the similarities between Brakel's $H M H$ and Add. 8149 can be found in the different versions of $D M J$.

\section{Part II}

Brakel noted that similarities between $H M H$ and the Persian manuscript (Add. 8149) are also present in part II. As mentioned earlier, he said that chapters 1-17 and 20-21 of the second part are found in MS Add. 8149 in the British Library. And this is also the case when $H M H$ and $D M J$ are compared. For instance, the first chapter of part II of Add. 8149, as well as of GA and NP, starts by telling how a servant informed Muhammad Hanfiyyah of the death of his brother(s), after which Muhammad Hanfiyyah tore his clothes. ${ }^{45}$

Also, in both GA and NP, the names of people and events are largely similar to those of $H M H$; for instance, in both the Persian and Malay versions, Muhammad Hanafiyyah sent messages to his brothers who were living in various parts of the world:

- GA: "maktūb bi-jānib-i Mashīb bi-Kāqah nivisht va dar 'Irāq firistād [...] yik maktūb bar Tughān Turk, Amīr-i Tabrīz nivishta [...] va yik maktūb bi-țaraf-i 'Umar 'Ali, Talīb-va 'Aqūl 'Alī nivishta dar Shām firistād [...]" ("[he] sent letters to Mashīb bi-Kāqah (?) in Iraq [...] one letter [was] sent to Tughān Turk, the ruler of Tabriz [...] and one letter he sent to 'Umar 'Alī, Ṭālīb 'Alī and 'Aqīl 'Alī in Shām [...]').

- NP: ["Muhammad Hanīfah] farmūd ki tā dabīr-i dānā [...] maktūb bi-jānibi-i Masīb Qa'qa'ah bi-nivīsad [...] nāma bi jānib-i Mas̄̄b Qa'qa'ah dar 'Irāq firistāda shud,[...] va yik maktūb bi-jānib-i Ibrāhīm [Ashtar] nivishta karda dar shahr-i Najaffiristād [...] maktūb-i siyyum bi jānibi-i Tughān Turk samt-i Tabrīz nivishta kard [...] va maktūb-i chahārum bi-jānib-i [...] 'Umar 'Alī, Mațlab 'Alī va 'Aqūl 'Alì dar Shām firistād [...]" ("[He] told his wise secretary to write a letter to Masīb Qa'qa'ah [...] the letter was sent to Masīb Qa' qa'ah in Iraq [...]

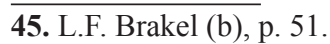


and one letter was written to Ibrāhīm [Ashtar] and sent to Najaf [...] the third letter was written to Tughān-i Turk in Tabriz [...] and the forth one was sent to 'Umar 'Alī, Maṭlab 'Alī and 'Aqūl 'Alī in Shām $\left.[\ldots]^{\prime \prime}\right)$.

- HMH: "[...] sembilan kami bersaudara: seorang namanya Umar Ali [...] Talib Ali, Akil Ali benua Baghdad [...] Sebermula anak-anakan bapaku Syahi Mardan Ali, Masib Kaka namanya, [...] benua Irak [...] Bermula Ibrahim Astar, anak raja benua Tuj 'ah [...] Tughan Turk dan Mughan Turk, benua Tabriz [...]"46 ("[Muhammad Hanafiyyah and 'Alī Akbar] addressed our [i.e. their] nine brothers: 'Umar 'Alī, Ṭālib 'Alī and Aq̄il 'Alī in Baghdād [...] the son of my father, Shah Mardan Ali, whose name is Masib Kaka [...] in Iraq [...] Ibrāhim Astar, the son of the king of Tuj 'ah [...] Tughan Turk and Mughan Turk from Tabriz").

It seems that Mughan Turk, who accompanies Tughan Turk in the revenge story in $H M H$ is known as Sayalān/Saylān Turk in GA and Asad Turk in NP.

There is yet another similarity: the animals that appear in both $H M H$ and $D M J$ are the same: e.g. horse, elephant, camel, etc. Furthermore, the names of the allies of Yazīd, Marwān and 'Utbah b. Walīd are largely similar:

- GA: Khāqān-i Chìn, Habashī (from "Khaqan of China and Abyssinia")

- NP: Khāqān-i Chīn; Zang-bār, Habashī (from "Khaqan of China, Zanzibar and Abyssinia")

- HMH: Feringgi, Cina, Habsi, Zanggi (Franks [Portuguese(?)], China, Abyssinia, Zanzibar)

Although the Franks are not listed as allies of Yazīd in the versions of $D M J$ here examined, the rest of the story in GA calls the enemy of Muhammad Hanafiyyah Khäriji-ān, which means "Franks."

B) Common Points between DMJ and HMH which are NOT found in Add. 8149

Brakel stated that chapters 1 and 5-20 of part I and chapters 18-19 and 22 of part II of the Malay HMH are not found in the Persian manuscript Add. 8149. However, it will be seen that the stories from these Malay chapters are, on the other hand, found in the $D M J$ versions. Examples include:

$\overline{\text { 46. Ibid., pp. 206-207. }}$ 


\section{Part I}

\begin{tabular}{|l|}
\hline \multicolumn{1}{|c|}{ Brakel's edition of $\boldsymbol{H M H}$} \\
\hline Chapter 1: Muhammad is unable \\
to recite but Gabriel instructs \\
him to do so. It is expressed that \\
Gabriel is henceforth as a brother \\
to the Prophet.
\end{tabular}

Chapter 6: Muhammad becomes ill; his close companions understand about the approaching death of the Prophet; the Companions' responsibilities during the funeral are detailed.

Chapters 8 and 9: the death of Fātimah after seeing her father, Muhammad, in a dream; how 'Alī and his sons buried Fātịmah; the Companion's demand for the body; how 'Alī "became furious and put on battle-dress [...]", as well as the Prophet's recommendation to $\mathrm{Abu}$ Bakr that "all of mankind together was no match for "Alī when dressed like this."

Chapter 12: Shahr-Banun wanted to choose her husband; she rejected Hassan because he was a polygamist.

\begin{tabular}{|c|c|}
\hline GA & Additional Comments \\
\hline $\begin{array}{l}\text { "[...] ey farzandānam man } \\
\text { dar așl nivishtan nimidānam } \\
\text { [...] Jibra "̄l 'alayh al-salām } \\
\text { dar-rasīd" ("O my children, I, } \\
\text { indeed, cannot read and write } \\
\text { [...] Gabriel then came"). }\end{array}$ & $\begin{array}{l}\text { Muhammad'silliteracy is clearly explained } \\
\text { in GA when Hassan and Husayn show } \\
\text { their handwriting to Muhammad. Also, } \\
\text { throughout OP, Muhammad frequently } \\
\text { addresses Gabriel as his brother (barädar/ } \\
\text { akhī). }\end{array}$ \\
\hline 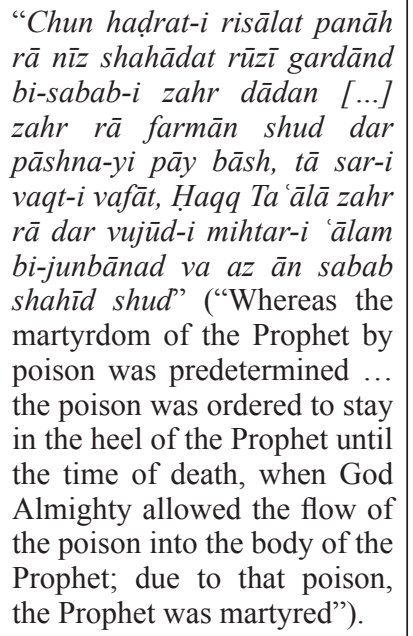 & $\begin{array}{l}\text { Although } D M J \text { talks about the death of } \\
\text { Muhammad, its quality differs from that } \\
\text { of } H M H \text {. } \\
\text { However, the GA ms. starts with a } \\
\text { qur' anic verse about martyrdom: "And } \\
\text { do not say about those who are killed in } \\
\text { the way of Allah, 'They are dead.' Rather, } \\
\text { they are alive, but you perceive [it] not". } \\
\text { Later, it talks about the death/killing of } \\
\text { the Companions and the first four caliphs, } \\
\text { whose names and deaths are mentioned } \\
\text { in the 6th, 9th, 13th, 14th, 15th, and other } \\
\text { chapters of part I of } H M H \text {. } \\
\text { Nonetheless, different stories about the } \\
\text { death of Muhammad and the Companions' } \\
\text { roles are found in other chapters of } D M J \text {, } \\
\text { which will be discussed in subsequent } \\
\text { studies. }\end{array}$ \\
\hline 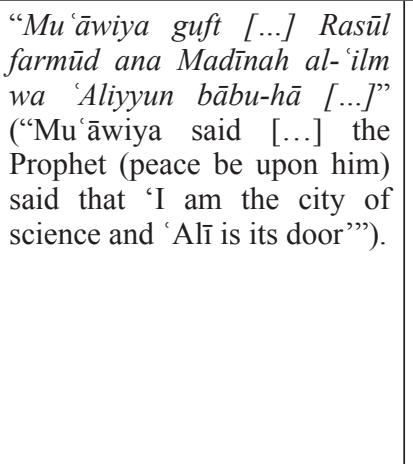 & 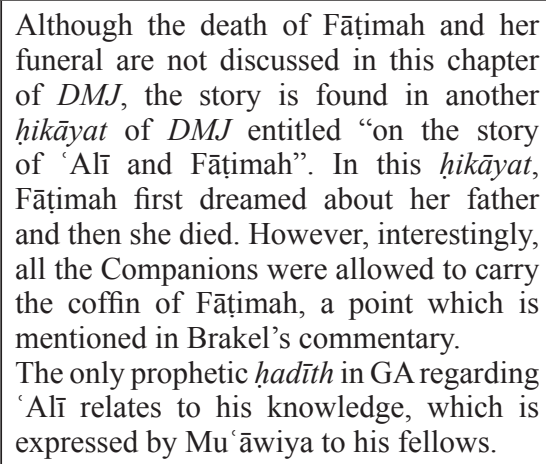 \\
\hline $\begin{array}{l}\text { "Imām Hassan zanān-i bisyār } \\
\text { dāsht va rahā karda būd; } \\
\text { guyand haftād-u du tan zan } \\
\text { karda [...]" ("Imām Hassan } \\
\text { had many wives and he left } \\
\text { them/divorced them; it is said } \\
\text { that he had } 72 \text { wives [...]"). }\end{array}$ & $\begin{array}{l}\text { GA does not refer to the Hassan's interest } \\
\text { in Shahr-Bānü; however, there are several } \\
\text { references to his polygamous lifestyle, } \\
\text { which caused his wife to give him a } \\
\text { poisoned drink. }\end{array}$ \\
\hline
\end{tabular}




\section{Part II}

\begin{tabular}{|c|c|c|}
\hline $\begin{array}{l}\text { Brakel's edition of } H M H \text { in } \\
\text { Part II }\end{array}$ & GA & Additional Comments \\
\hline $\begin{array}{l}\text { Chapter } 18 \\
\text { "Tughan Turk and Mughan Turk } \\
\text { had set out to intercept the army } \\
\text { of the Zanggi" }\end{array}$ & $\begin{array}{l}\text { "Va Tughān-i Turk va } \\
\text { Sayalān-i/ Saylān-i Turk bā } \\
\text { chihil hizāar savār muqābil-i } \\
\text { Habashī shudand" ("And } \\
\text { Tughan Turk and Sayalān/ } \\
\text { Saylān Turk, along with } \\
\text { their 40,000-strong army, } \\
\text { intercepted the army of } \\
\text { Abyssinia"). }\end{array}$ & \\
\hline $\begin{array}{l}\text { Chapter 19: A mighty battle } \\
\text { between Yazīd and Muhammad } \\
\text { Hanafiyyah and "the fighting } \\
\text { became still more violent" }\end{array}$ & 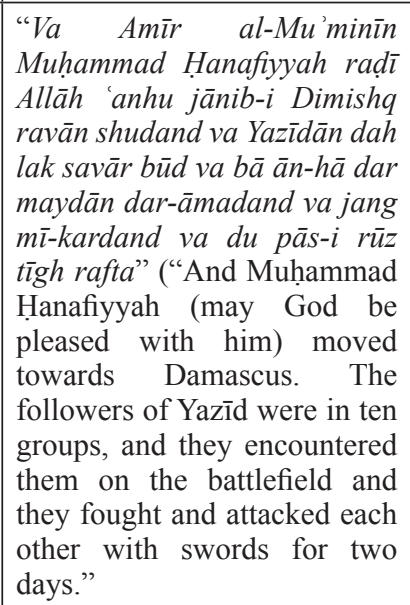 & \\
\hline
\end{tabular}

\section{Further Discussion of Earlier Literature}

\section{Discussion of Earlier Arguments}

The above sections have tried to show the strong connection between $D M J$ and $H M H$. However, this section provides readers with more analysis of recent literature:

1. The references to Tughan Turk, the Emir of Tabriz, in DMJ's 31st chapter on the death of Hassan and Husayn confirms the claim of both Brakel and Bausani that this story must originally have been written when Tabriz was the capital of Persia under Ghaza Khān in the 13th and early 14th century ${ }^{47}$. Also, the name of Zahrāb as the one who killed Husayn's infant, as found in the DMJ copy in Michigan, had been already mentioned in Firdawsî̀'s Shāh-nāma. A couplet by Sa 'dī

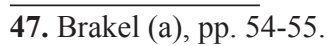


is also found in $D M J$ 's manuscripts. These details put together help us to conclude that $D M J$ was probably composed in the 13th century.

2. As mentioned above, this article seeks only to uncover the possible origins of $H M H$, rather than to discuss the process by which it was translated from Persian or the production of $H M H$ and additions made by Malay scribes. However, it should be noted that DMJ's account of Hassan and Husayn's death and of Muhammad Hanafiyyah may disagree with both Brakel and Braginsky, particularly in the second part.

a. Brakel stated that he was unable to find a parallel for [I4:] how Mu'āwiya's son, Yazīd, was conceived. As such, he stated that $H M H$ "exempted Mu'āwiya from any blame. Yazīd is reviled again and again because of his illegitimate birth [...]."48

b. Braginsky argued that:

Another peculiarity of the tale, which is largely a Malay innovation, is the strict division of its characters into two camps. The first of them, headed by Muhammad Hanafiyyah, is connected with the divine world, as is indicated by prophetic dreams of the main hero and wonderful events that happen to him. The second, headed by Yazid, is connected with the demonic world, as is testified to, for instance, by Yazid's begetting of Mu'awiah, poisoned by a scorpion's venom, and an old black Ethiopian woman $[\ldots]^{49}$.

These scholars believed that the episode of Mu'âwiya and the scorpion was not found in Persian sources. Yet, as seen previously, Yazìd's connection "with the demonic world" is clearly shown in the DMJ mss.; indeed, all available $D M J$ manuscripts state that Mu'āwiya was poisoned by a scorpion's (kazhdum) venom and that then, to cure himself, he was advised to have sex with a woman, an event which ultimately led to the birth of Yazid. GA in particular presents Yazìd's mother as an insignificant female slave (kanīzak). Interestingly, this infelicitous image of Yazidd's birth is also seen on fl. 51 of a poetic Bengali version of Jang-nāma-i Imām Husayn (Isl. Ms. 853), preserved in the special collections of the University of Michigan.

It is true that $H M H$ tried to portray Mu 'āwiya as a faithful Companion of Muhammad, although it did not come to the attention of earlier scholars that part I of the $D M J$ mss. in general, and of the GA in particular, is replete with stories that exempt $\mathrm{Mu}$ ' āwiya from any wrongdoing. For instance, on fol. 132 of GA, there is a report that highlights Yazīd's mistake and then says:

"[...] in makr-i Yazīd būd va ba' d̄̄ bar Mu 'āwiya idāfat mīkunand, bizih-kār mīshavand zìrā-ki Mu'āwiya az kibār-i Șaḥābah būd va kätib-i vahy būd va Rasūl Allāh 'Alayh wa-sallam guft harkas bi-dhikr-i nīk yād kunad așhāb-i man, $\bar{u}$ rā ast bihisht pas har-

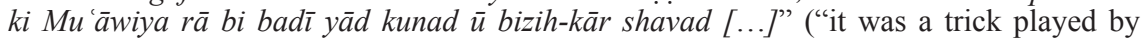

48. Brakel (b), p. 7.

49. Braginsky, 2005, p. 183. 
Yazīd, however, one which some people ascribed to Mu'āwiya, though they are sinners, as $\mathrm{Mu}$ 'âwiya was one of the Companions and the writer of the revelation, and the Prophet of God said 'whoever remembers my Companions well, he deserves Paradise'; thus, anyone who remembers Mu'āwiya badly is a sinner [...]").

Brakel also agreed that only an Acehnese manuscript-Or. 8667mentions both Yazīd and Mu'āwiya "as fellow Muslims". However, there is a point worth mentioning regarding GA: when Mu'āwiya learned about the pregnancy of his female slave he wanted her to have an abortion because Yazīd was cursed, "however, the opinion of Sunnis is not to curse Yazìd, and this is the true opinion" ("va qawl-i ahl-i Sunnat va Jamā'at in ast ki Yazìd rā la 'nat nakunad ki hamīn șahīh ast').

Also, in both GA and NP manuscripts the Muhammad Hanafiyyah section not only starts with a letter carried by the servant but it is also bolstered by a prophetic dream in which Muhammad told him:

(GA, fol. 149) "[...] ey farzandān, $\bar{u}$ rā bikush ki man bā tu hastam va hīch khațā va uft va nikbatī bar tu nakhāhad rasìd va tu-rā fath va nușrat khāhad shud" ("Oh my children, kill him [Yazīd] and know that I am with you and you will not receive blame, loss and misery, and you will be victorious [...]").

(NP, fol. 495) "[...] ammā fath va nușrat bi-nām-i nāmi-yi tu bar lawh-i azal nivishta-and va dar zadan-i dushman-i khänah-dän va asīr numüdan-i ìshān dirang makun" "but your conquering and victory has been carved on the eternity plate [or: on the plate of eternity], and do not be patient in beating and capturing the enemies of the family [...]").

1. As mentioned earlier, Winstedt, Voorhoeve, and Brakel have all pointed out that some Malay versions of $H M H$ are prefaced with another mystical story about the creation of Muhammad and his light, i.e. Hikayat Nur Muhammad (HNM), which is not found in Add. 8149. Indeed, they are still uncertain whether part I (the killings of Hassan and Husayn), part II (the Muhammad Hanafiyyah revenge story), and $H N M$ are found in one manuscript or whether both the Persian and Malay versions were "one unified text, consisting of two or more parts, or $[. .$.$] two or more originally independent fragments which have been$ combined." 50

To provide an answer to such uncertainties, and before referring to $D M J$, Brakel's statement should be examined:

In Acehnese literature these three [I. HNM.; II Hikayat Hasan dan Husain (= part one); III $H M H$ (= part two)] are still found separately. In Malay, one finds separate copies of the $H N M$ (in many different redactions) but perhaps only one ms. of a separate Hikayat Hasan dan Husain, and as far as I know no separate mss. of the Hikayat Muh. Hanafiyah proper. II and III at least are translations from Persian, and they are already found combined in a ms. of the Persian original (Br. Mus. Add. 8149) [...] in our ms. however the beginning of III is clearly marked ${ }^{51}$.

$\overline{\text { 50. Brakel (a), p. } 16 .}$

51. Ibid. 
Now, let's discuss it as follows:

a. The above structure described by Brakel is found in $D M J$, as well. In most of the DMJ manuscripts, The Story of the Killing of Hassan and Husayn (part I) is separate from that of Muhammad Hanafiyyah (part II). In some cases, however, as in GA and NP, it is not.

b. Although there are many paragraphs in $D M J$ that highlight the creation of Muhammad, the GA ms. ends with a story called Nür-näma-yi Hadrat-i Rasūl Allāh ("The Book of the Light of the Prophet") (part III) (fols: 158-62), which is about the creation of Muhammad from light. This work is largely similar to the Persian, Arabic, and Malay $H N M$. It starts with a conversation between Gabriel and Muhammad in which the latter tells the former: $\bar{u}$ sitārah az nūr-i man ast ("that star is from my light"). The story ends by mentioning the existence of 990 copies of Nür-nāma during the lifetime of Muḥammad Ghazāli and references to the particular attention that Mahmūd of Ghazna had paid to it (fig. 3).

c. Also, other versions of $D M J$, such as 14248 , preserved in the library of the Parliament in Tehran, are bound with other stories, such as the Wafāt-nāma; these stories are largely similar to that of Muhammad's death as it appears in $H M H$.

Obviously, whether part I, II, and III are or are not separate can be seen in the various $D M J$ MSS. Malay scribes seem to have followed or been influenced by the way in which $D M J$ was written or copied by Muslims in Central or South Asia.

\section{Final remarks}

This study has shown how Muhammad Ḥanafiyyah, whose role is frequently seen in the legendary part of the text (part II), was indigenized and established as the hero of a particular region. It shows that scribes tried to localize Muhammad Hanafiyyah to make him one of their own, ruling a territory that was not limited to Boeniara. Moreover, although Brakel and other scholars opined that $H M H$ is based on the Persian manuscript Add. 8149 in the British Library, this article has shown the possibility that $H M H$ was dependent on the Persian text $D M J$, which has been studied for the first time here. Interestingly enough, not only is $D M J$ 's story older but it is also more detailed than the Add. 8149 manuscript, so that those chapters of $H M H$ whose parallels Brakel could not find in Add. 8149 do appear in $D M J$. Furthermore, the final question posed by earlier scholars regarding the link between $H N M$ and parts I and II of $H M H$ has been answered, as $D M J$ manuscripts also place part I and II of $H M H$ alongside $H N M$. Finally, this essay has tried to build on earlier literature to shed more light on the Persian origin of $H M H$. 


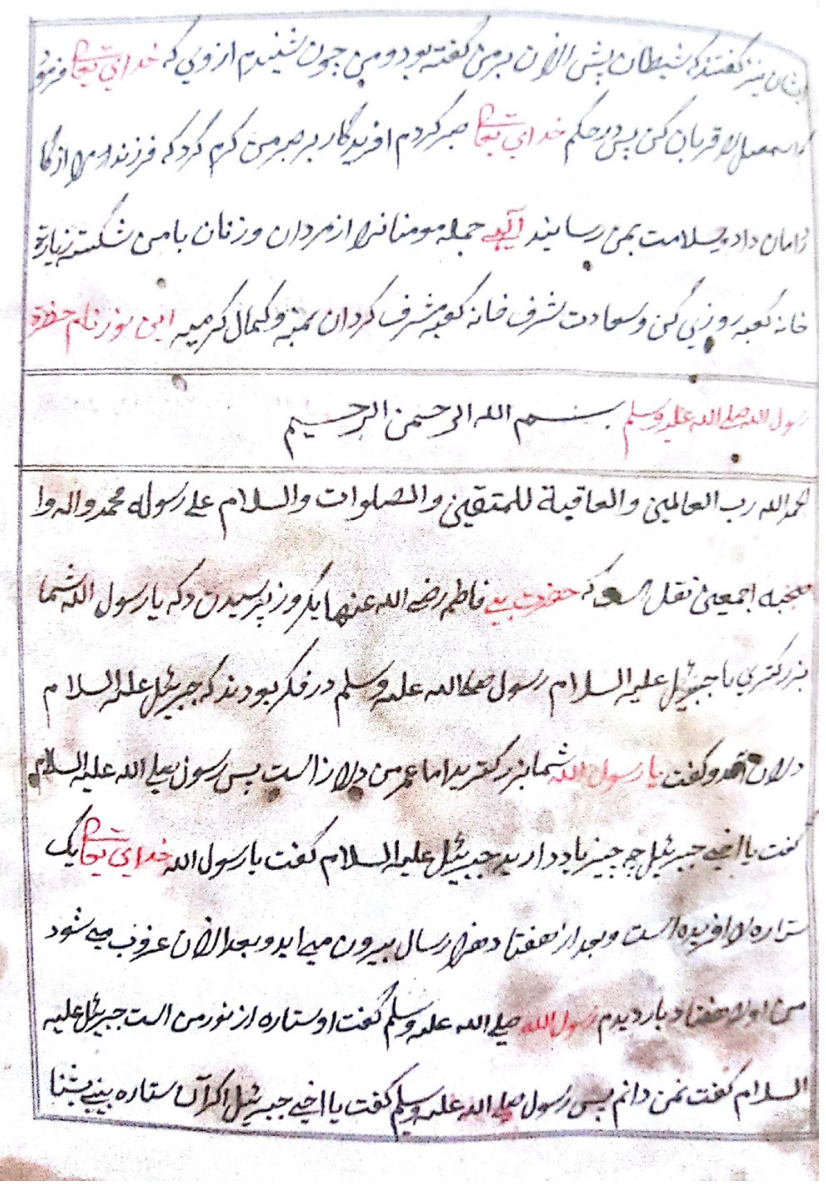

Fig 3 - Nūr-nāmah-yi Haḍat-i Rasūl Allāh, GA ms. 


\section{Appendix}

\section{The $D M J$ manuscripts available to the author}

1. MS Or. 565, Leiden University Library, Leiden

2. MS Or. 877, Leiden University Library, Leiden

3. MS 170, Auckland Libraries, Auckland

4. MS 853, University of Michigan Special Collections Library, Michigan

5. Cod. Pers 187, Staatsbibliothek, Munich

6. Cod. Pers 188, Staatsbibliothek, Munich

7. MS 29, The National Library of Iran, Tehran

8. MS 258, The National Library of Iran, Tehran

9. MS 27641, The National Library of Iran, Tehran

10. MS 33429, The National Library of Iran, Tehran

11. MS 14248, Iranian Parliament Library, Tehran

12. MS 19495, Iranian Parliament Library, Tehran

13. MS 53, Talaat Library, Cairo

14. PAK-001-0770, Ganj Bakhsh, Islamabad

15. PAK-001-1043, Ganj Bakhsh, Islamabad

16. PAK-001-1471, Ganj Bakhsh, Islamabad

17. PAK-001-0487, Ganj Bakhsh, Islamabad

18. PAK-001-1180, Ganj Bakhsh, Islamabad

19. PAK-001-1506, Ganj Bakhsh, Islamabad

20. PAK-001-1666, Ganj Bakhsh, Islamabad

21. PAK-001-1498, Ganj Bakhsh, Islamabad

22. PAK-001-2123, Ganj Bakhsh, Islamabad

\section{The Catalogue-based examination of DMJ Manuscripts}

23. MS 40539, Central Library of Astan Quds Razavi, Mashhad

24. MS 40550, Central Library of Astan Quds Razavi, Mashhad

25. MS 40551, Central Library of Astan Quds Razavi, Mashhad

26. MS 27706, Central Library of Astan Quds Razavi, Mashhad

27. MS 46429, SOAS Library, London

28. MS 1959, Kaiserlich-Königlichen Hofbibliothek zu Wien, Vienna

29. MS 26/1, Library of Dargah Aliyah Mahdaviyh, Palanpur, Gujarat

30. MS Corpus, No. 88, Libraries of the University and Colleges of Cambridge, Cambridge

31. MS Egerton 1026, British Museum (now British Library), London

32. Nos. 1762 and 1882, 83, 84, 85, 86, 87, 88, 89, India Office Library, London

33. MS 40539, Central Library of Astan Quds Razavi, Mashhad 
34. MS 40550, Central Library of Astan Quds Razavi, Mashhad

35. MS 40551, Central Library of Astan Quds Razavi, Mashhad

36. MS 27706, Central Library of Astan Quds Razavi, Mashhad

37. Sh. 211, National Library of Tajikistan, Dushanbe

38. Sh. 201, National Library of Tajikistan, Dushanbe

39. Cod. 19, The Russian State Library/V. I. Lenin State Library of the USSR, Moscow

40. Cod. 20, The Russian State Library/ V. I. Lenin State Library of the USSR, Moscow

41. Cod. 2870, Academy of Sciences of Turkmenistan, Ashgabat

42. MS B 1006, The Institute of Oriental Studies of the Russian Academy of Sciences/ Institute of Oriental Studies of the USSR Academy of Sciences, Moscow

43. MS 12750, Mar 'ashi Najafi Library, Qum

44. MS 10680, Mar 'ashi Najafi Library, Qum

45. MS 54, McGill University Persian Manuscripts, Québec

46. MS 5777, Imam Sadiq University, Tehran

47. MS 544, Nikolay Lobachevsky Scientific Library, Kazan

48. MS 545, Nikolay Lobachevsky Scientific Library, Kazan

49. MS 546, Nikolay Lobachevsky Scientific Library, Kazan

50. MS 547, Nikolay Lobachevsky Scientific Library, Kazan

51. MS 548, Nikolay Lobachevsky Scientific Library, Kazan

52. MS 549, Nikolay Lobachevsky Scientific Library, Kazan

53. MS 550, Nikolay Lobachevsky Scientific Library, Kazan

54. MS 551, Nikolay Lobachevsky Scientific Library, Kazan

55. MS 552, Nikolay Lobachevsky Scientific Library, Kazan 